\title{
WestVirginiaUniversity
}

THE RESEARCH REPOSITORY @ WVU

Graduate Theses, Dissertations, and Problem Reports

2008

\section{Essays on evidence and effects of international movements of capital and labor}

\author{
Sudeshna Pal \\ West Virginia University
}

Follow this and additional works at: https://researchrepository.wvu.edu/etd

\section{Recommended Citation}

Pal, Sudeshna, "Essays on evidence and effects of international movements of capital and labor" (2008). Graduate Theses, Dissertations, and Problem Reports. 2693.

https://researchrepository.wvu.edu/etd/2693

This Dissertation is protected by copyright and/or related rights. It has been brought to you by the The Research Repository @ WVU with permission from the rights-holder(s). You are free to use this Dissertation in any way that is permitted by the copyright and related rights legislation that applies to your use. For other uses you must obtain permission from the rights-holder(s) directly, unless additional rights are indicated by a Creative Commons license in the record and/ or on the work itself. This Dissertation has been accepted for inclusion in WVU Graduate Theses, Dissertations, and Problem Reports collection by an authorized administrator of The Research Repository @ WVU.

For more information, please contact researchrepository@mail.wvu.edu. 


\title{
Essays on Evidence and Effects of International Movements of Capital and Labor
}

\author{
Sudeshna Pal \\ Dissertation submitted to the \\ College of Business and Economics \\ at West Virginia University in partial \\ fulfillment of the requirements for the degree of \\ Doctor of Philosophy \\ in \\ Economics \\ Santiago Pinto, Ph.D., Chair \\ Ashok Abbott, Ph.D. \\ Arabinda Basistha, Ph.D. \\ Alexei Egorov, Ph.D. \\ Hyungna Oh, Ph.D. \\ Department of Economics \\ Morgantown, West Virginia \\ 2008
}

Keywords: Capital Mobility, Feldstein-Horioka Puzzle,

Immigration, Outsourcing, Labor Income Tax

Copyright 2008 Sudeshna Pal 


\section{Abstract \\ ESSAYS ON EVIDENCES AND EFFECTS OF INTERNATIONAL MOVEMENTS OF FACTORS}

\section{Sudeshna Pal}

This dissertation presents three essays on the evidence and effects of international mobility of capital and labor. Essay 1 explores the behavior of this coefficient in OECD countries over a thirty year period. The second and third essays focus on international movements of labor measured by immigration and outsourcing. The second essay theoretically examines the impact of low skill outsourcing on domestic tax rates, namely labor tax and profit tax. The third essay empirically shows the impact of low skilled immigration and outsourcing on labor tax rates in OECD countries. What follows is a summary of the essays.

The first essay, "Reassessing International Capital Mobility: The Feldstein-Horioka Puzzle Disappears" examines how capital mobility changed over the years, especially during the 1990s often termed as the era of globalization. Feldstein - Horioka type regressions using pooled annual data for OECD countries show that savings-investment correlations fall continuously throughout the 1990s implying increasing capital mobility. This is in sharp contrast to the fairly stable behavior of the coefficient till late 1980s. Evidences show that the phenomenon is indeed global and not country specific. Current account data also confirms increased capital mobility. Developing countries too become financially integrated during the 1990s, but they had an earlier start than OECD nations.

The second essay, "Outsourcing and Domestic Tax Policy", is a theoretical depiction of the impact of foreign outsourcing on domestic tax rates. The model includes two types of workers, namely managers or high skilled workers who also own the firms and workers who are low skilled and are hired by the managers. An individual can choose to become either of the two given his innate ability and the cost of acquiring skills. In addition, we introduce outsourcing as a factor in a firm's decision making. The firms or managers can hire native workers and outsource jobs abroad. The government taxes both labor income and profit income and provides transfers. The tax rates are determined through a process of voting in which the median voter plays a pivotal role. Our model shows that if the domestic firms increase foreign outsourcing, labor tax rates decline and profit tax rates increase unambiguously in the home country.

The third essay, "Immigration, Outsourcing and Tax Policy: Evidence from OECD Countries" studies effects of immigration and outsourcing on domestic labor tax rates. Immigration and outsourcing are typically portrayed as substitutes in production and in terms of their effects on the domestic economy. A political economy analysis shows that immigration and outsourcing may actually have very different impact on the domestic economy, so that they may not be viewed as "substitutes" anymore. A study on 15 OECD countries finds that while low skilled immigration increases tax burden on domestic labor, low skilled outsourcing may actually reduce it. Low skilled immigration may impose additional fiscal burden and thus lead to higher tax rates on labor. Outsourcing of low skilled jobs, on the other hand, does not make any claims on government transfers and therefore, may result in lower domestic labor tax rates. 


\section{Acknowledgements}

I would like to thank my committee members Santiago Pinto, Ashok Abbott, Arabinda Basistha, Alexei Egorov and Hyungna Oh, for their time and useful advice. I am immensely grateful to all of them. I would especially like to thank my advisor Dr. Pinto for being a wonderful guide and for being so supportive and caring. I have learnt so much from him. I want to convey my special thanks to Dr. Subhayu Bandyopadhyay and Dr. Basistha for providing very useful comments on my research. I shall be ever grateful to Prof. Balvers for being so reachable and supportive whenever I sought his advice on some crucial issues.

I would also like to acknowledge the advice and moral support I received from my friends and colleagues during my years as a graduate student, especially Seth, Anasua and Parag.

Finally, I wish to thank my family and most importantly my parents, who have been a constant source of support and encouragement even from thousands of miles away. 


\section{Contents}

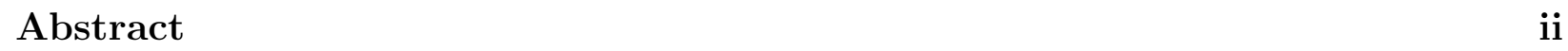

\begin{tabular}{|ll}
\hline Acknowledgements & iii
\end{tabular}

$\begin{array}{lll}1 & \text { Purpose and Agenda } & 1\end{array}$

2 Reassessing International Capital Mobility: The Feldstein-Horioka Puzzle

Disappears 5

1 Introduction . . . . . . . . . . . . . . . . . . . 5

2 Literature Review . . . . . . . . . . . . . . . . . . . . . . . . 8

3 Saving-Investment Correlations . . . . . . . . . . . . . . . . . . . . 11

$3.1 \quad$ Sample Sensitivity and Robustness Tests . . . . . . . . . . . . . . . . 12

4 Current Account and Capital Mobility . . . . . . . . . . . . . . . . . . 13

5 Developing Countries . . . . . . . . . . . . . . . . . . . 15

6 Conclusion . . . . . . . . . . . . . . . . . . 16

\begin{tabular}{|ll}
3 & Outsourcing and Domestic Tax Policy \\
\hline
\end{tabular}

1 Introduction . . . . . . . . . . . . . . . . . . . . 24

2 Related Literature . . . . . . . . . . . . . . . . . . . . . . . 25

3 The Model . . . . . . . . . . . . . . . . . . . . . . . . 26

$3.1 \quad$ Firm's Problem and Occupational Choice . . . . . . . . . . . . . . . . 27

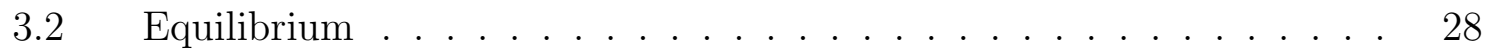

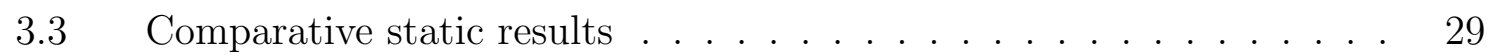

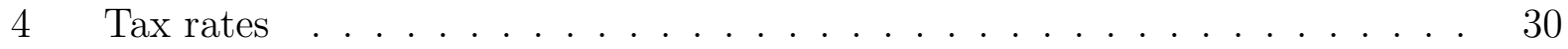

$4.1 \quad$ Labor tax rate . . . . . . . . . . . . . . . . . . . . . . . . . . . . . . . . . . . . . . . . . . . . .

4.2 Profit tax rate . . . . . . . . . . . . . . . . . 33

5 Conclusion $\ldots \ldots \ldots \ldots$. . . . . . . . . . . . . . . . . . . . . . . 34

4 Immigration, Outsourcing and Tax Policy: Evidence from OECD Countries $\quad 38$

$1 \quad$ Introduction . . . . . . . . . . . . . . . . . . . . . . 38

$2 \quad$ Conceptual Framework and Related Literature . . . . . . . . . . . . . . . . . 40

$2.1 \quad$ Immigration and Tax Policy . . . . . . . . . . . . . . . . . . . . 41

$2.2 \quad$ Immigration, Outsourcing, and Labor Productivity . . . . . . . . . . 43

$2.3 \quad$ Outsourcing and Tax Policy . . . . . . . . . . . . . . . . . . . . 44 


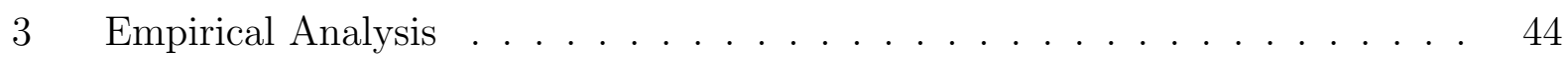

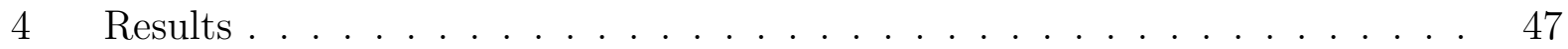

5 Conclusion . . . . . . . . . . . . . . . . . . . . . . 52

\begin{tabular}{llr}
\hline 5 & Conclusion & 58
\end{tabular}

\begin{tabular}{ll}
\hline Bibliography & 60
\end{tabular}

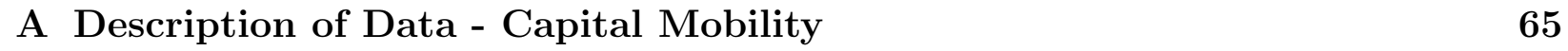

B Detailed description of "Labor tax rate" and "Outsourcing" measures 67

\begin{tabular}{ll}
\hline C Data Sources & 70
\end{tabular}

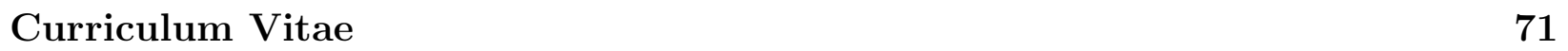




\section{List of Figures}

2.1 S-I Correlation Coefficient for OECD Countries . . . . . . . . . . . . . . 17

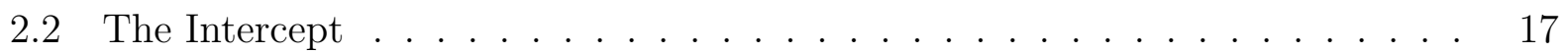

$2.3 \quad$ Current Account-Investment and S-I Correlations . . . . . . . . . . . . . 18

2.4 S-I Correlations for OECD and Developing Countries . . . . . . . . . . . 18

$4.1 \quad$ Effective labor tax rate in 15 OECD countries, 1990-2001 . . . . . . . . . . 53

4.2 Share of migration in total population in 15 OECD countries, 1990-2001 . . 53

$4.3 \quad$ Outsourcing in 15 OECD countries, 1990-2001 $\ldots \ldots \ldots \ldots$ 


\section{List of Tables}

$2.1 \quad$ Saving Investment Correlation Coefficients for 29 OECD Countries . . . . . 19

2.2 Full Sample vs. Subsample Estimates . . . . . . . . . . . . . . . . . . 20

2.3 Current Account Approach to the FH puzzle . . . . . . . . . . . . . . . . . . . 21

2.4 FH Approach vs. Current Account Approach. . . . . . . . . . . . . . . . . . 22

2.5 FH-Coefficient for Developing Countries . . . . . . . . . . . . . . . . . . 23

3.1 Optimal labor tax rate for workers: different levels of outsourcing . . . . . . 36

3.2 Optimal labor tax rate for managers: different levels of outsourcing . . . . . 36

3.3 Optimal profit tax rate for workers: different levels of outsourcing . . . . . . 37

3.4 Optimal profit tax rate for managers: different levels of outsourcing . . . . . 37

4.1 Summary Statistics . . . . . . . . . . . . . . . . . . . . . . . 55

4.2 Correlation Coefficient Matrix: All countries . . . . . . . . . . . . . . . . . 56

4.3 Effect of Immigration and Outsourcing on Labor Tax Rate . . . . . . . . . . 57 


\section{Chapter 1}

\section{Purpose and Agenda}

International integration of factor markets ensures efficient allocation of resources on a global level. The inherent trade off between efficiency and equity most naturally becomes an issue in studying globalization of factor markets. The 1990s, typically viewed as the era of globalization was marked by capital market deregulations in developed economies. Capital moved out from these economies to other parts of the world both in the form of FDI and outsourcing. It is the latter form of capital movement that we focus on. The increased global mobility of the relatively mobile capital in turn affected the market for relatively immobile factors, namely, unskilled labor. The purpose of this study is first, to examine the degree

of globalization in international capital markets and then focus on public finance effects of outsourcing on domestic unskilled labor, and also compare the results with international immigration effects.

The analysis thus begins with an open economy macroeconomics approach towards assessing the degree of international capital mobility. The empirical results show phenomenal increase in capital mobility in the past few decades. The study then adopts a microeconomic approach to analyze the impact of outsourcing on labor income tax. A political equilibrium model shows that outsourcing increases the burden of income tax on domestic unskilled labor. The theory thus established will then be verified empirically. The entire study fo- 
cuses on OECD countries as these are capital abundant economies and have opened up their financial markets in the era of globalization.

The outcomes of this analysis, apart from providing new insights about international factor market integration, also contradicts some existing theories and evidences in international trade and finance. The findings are presented in the form of three essays.

Chapter 2, titled, "Reassessing International Capital Mobility: The Feldstein-Horioka Puzzle Disappears", examines the degree of capital mobility in OECD countries. Savinginvestment correlation coefficient acts as an indicator of international capital mobility. Pooled cross-section time-series regressions show that capital in OECD countries changed from being almost perfectly immobile between the seventies and early nineties to nearly perfectly mobile during the late nineties. These findings also show that the Feldstein-Horioka puzzle that capital was almost perfectly immobile across OECD countries has disappeared in the late nineties.

In a study by Feldstein and Horioka (date), they show that violating the theoretical foundations of intertemporal current account models, a sample of 16 OECD countries show that capital was almost perfectly immobile during 1960-1974. They measure capital mobility as the correlation coefficient between long term averages of domestic savings (S) and investment (I). Under perfect capital mobility this correlation coefficient should be equal to zero. They, however, find that the coefficient is close to one which means there is no international mobility of capital.

We estimate the Feldstein-Horioka regression for the period 1970-2003 for 29 OECD countries. The regression equation has the share of investment in GDP as the dependent variable and the share of savings in GDP as the explanatory variable. Our model uses annual data on savings and investment, following Sinn (1991) instead of long term averages. Annual data takes into account short-term movements of capital as much as it exposes the outcomes to short-term output fluctuations. Infact, a common criticism against the Feldstein-Horioka result is that saving and investment both are procyclical and hence appear to be correlated. 
The inclusion of an international business cycle term in our model accommodates for shortterm output fluctuations.

The value of the S-I correlation coefficient remain close to one for 1970s, 1980s. The coefficient starts to decline during the nineties and shows a sharp fall during the late nineties during which it approaches zero. Country by country tests prove the robustness of our results. The S-I correlation coefficient behaves in the same fashion for subsamples formed by leaving one country out at a time. This also proves that no one country is the driving force of our result and capital is indeed becoming almost perfectly mobile internationally.

Chapter 3, titled "Outsourcing and Domestic Tax Policy", provides a theoretical model explaining the effect of outsourcing on domestic labor and profit tax rates. The model rests on the median voter theory of taxation. In an economy consisting of two types of labor, namely managers or the high skilled and workers or the low skilled, an increase in foreign outsourcing of low skill jobs unambiguously drives down labor tax rates while causing profit taxes to rise in the domestic economy.

Chapter 4, namely, "Immigration, Outsourcing and Tax Policy:Evidence from OECD Countries" looks at the impact of outsourcing on labor income tax rate as opposed to that of immigration in OECD countries. Both immigration and outsourcing implies sharing the production process between domestic and foreign labor. The substitution of domestic unskilled labor by cheap foreign labor, whether in the form of hiring immigrants or outsourcing, is expected to yield similar labor market outcomes. Our study, however, shows that more indirect impact in terms of public finance implications are quite the opposite for the two.

As the global boundaries started to loosen over more than a decade now, factor mobility also got redefined. This is especially true for economically developed countries. Not only these countries attract cheap labor from the developing world, but they also send out part or whole of their own jobs to the labor abundant low income countries. Soon enough the cost saving strategies began to boomerang and strong feelings of insecurity spread among the domestic labor force of the advanced part of the world. The goal of this paper is precisely 
to examine from a political economy point of view the effects of international migration and outsourcing on public finance concerns by focusing on the resulting impact of these two alternatives on domestic labor taxes.

When a country's market opens up to cheap foreign labor force, either by immigration or by outsourcing, the domestic labor market is bound to get affected. Is their a difference as far as their impact on the domestic labor market is concerned? We claim that different levels of immigration and outsourcing affect domestic economic agents in conflicting ways. Hence, under majority voting, we expect different equilibrium levels of domestic labor tax rates chosen in each case. Evidences from OECD countries show that while low skilled immigration puts additional burden on domestic workers in the form of higher taxes, low skilled outsourcing actually reduces it. The finding also defies popular belief that immigration and outsourcing are two sides of the same coin.

The main conclusion of this study is that countries that opt for higher immigration than outsourcing will also end up with higher labor tax rates. The evidences also provide support for the theory that increase in low skilled outsourcing raises productivity of domestic low skilled workers. As these workers move up the income scale, they vote for lower taxes. Immigration, on the other hand, increases burden on the welfare state and hence leads to higher taxes. 


\section{Chapter 2}

\section{Reassessing International Capital}

\section{Mobility: The Feldstein-Horioka}

\section{Puzzle Disappears}

\section{Introduction}

Open economy macroeconomic policies rely heavily on inter-temporal models of current account. Current account balance in turn is a reflection of dynamic investment and savings behavior. A shortage or surplus in the domestic financial market is accommodated by international capital flows. The degree of international mobility of capital, therefore, has important macroeconomic implications. The ease with which an economy can borrow funds from the international capital market reflects its ability to cope with external shocks as well as internal impediments to private investment opportunities. Also, the degree of capital mobility acts as a measure of global financial integration.

Feldstein and Horioka (1980), tested the degree of international mobility of capital with 16 OECD countries for the period 1960-1974. They define the degree of capital mobility in terms of correlation between domestic investment and saving. The correlation coefficients 
for their sample were positive and close to one for almost every year. The implication was that capital was almost perfectly immobile among developed countries.

Research on the dynamics of international capital mobility has continued ever since. In a recent working paper, Feldstein(2005) mentions of his ongoing research on saving-investment correlations. The correlation declines significantly after 1995 for the OECD countries when he puts equal weights to the countries. He uses long term average data for his study. However, in his sample of 30 OECD countries the lowest value attained by the saving-investment correlation coefficient is 0.30 in 2001, whereas our analysis estimates this value to be almost equal to zero suggesting near perfect mobility of capital. A recent study by Ball (2006) studies the US economy and shows that though there have been no noticeable change in US trade flows, the degree of financial openness of the economy has gone up remarkably in recent years. These coupled with the KOF Index of Globalization (2007), that shows a sharp increase in economic globalization across the world and particularly so for the OECD countries during the late nineties forms the motivation behind our study of the evolving international financial market integration. In our attempt to do so we are able to establish that the degree of financial market globalization becomes significantly high in the past few years and the famous FH puzzle is on the verge of its disappearance. To the best of our knowledge no other research has considered looking at the dynamics of capital mobility in OECD countries during recent years using annual data and the methods used in this paper.

The goal of this study, as said before, is to examine how capital mobility evolved over time and whether it has really attained the perfection it possesses in macroeconomic theories. This analysis also aims to quantify the degree of international capital mobility. Our model uses Feldstein-Horioka type regressions using annual data and generates the dynamics and measurements of international capital mobility in 29 OECD countries for the period 19702003. Annual data on savings and investment shares of GDP, following Sinn (1991), apart from providing a generous dataset, yield exact year to year estimates of saving-investment correlations and do not require the intertemporal budget constraint. However, the data 
is likely to contain business cycle effects. Sachs et al. (1981) use a business cycle proxy constructed with detrended GDP. We use the same proxy to control for global business cycle effects. Eventually this study employs a pooled model with time dummies that yield exact year to year dynamics of how this coefficient behaves over time and across countries.

Several sensitivity analyses re-confirm the findings of the pooled regressions. Keeping in mind the spree of liberalization and integration with the $\mathrm{EU}$ that were in operation during the late nineties, it is reasonable to believe that capital mobility was more concentrated than global. Countries like Greece and Portugal, for instance were integrated to the EU during the nineties, an event followed by huge inflow and outflow of capital in these economies. Also the US economy has experienced phenomenal increase in financial openness since 1990. Moreover, KOF globalization indices 2007, reveal that the 15 most globalization nations are members of the OECD countries. We therefore account for the possible dominant effect of any single country in driving the results of the main regression by excluding a particular country from the dataset and re-estimating the model. This is done for each country in the whole sample.

An alternative estimation method, in particular, Sachs et al.'s (1981) current account approach is used to further reinforce the findings of our main regression. The alternative model, henceforth referred to as "the current account model", uses pooled data on share of current account surplus in GDP, as the dependent variable and share of investment in GDP as the explanatory variable. Investment turns out to be a significant determinant of and almost perfectly inversely related with current account balance. This re-confirms the dynamics of capital mobility found in the first model.

While the case for a near perfect capital mobility is made for the developed countries, the developing countries which are less favorable to a strong capital market are also tested for the degree of global financial integration. FH regression analysis for developing countries show that capital mobility in these countries in recent years is as high as the developed nations. However, the process of getting integrated to the global financial market started 
much earlier in the developing countries and has been consistently and gradually gaining strength since then.

The paper is structured as follows. Section 2 provides a brief account of past and present research on the issue. Section 3 presents the first regression with investment share in GDP as the dependent variable and savings share of GDP as the explanatory variable as well as the sensitivity tests. Section 4 shows the current account approach to measuring capital mobility. Section 5 analyses the case of developing countries. Section 6 concludes.

\section{Literature Review}

Feldstein and Horioka (1980) present an empirical critique of the perfect capital mobility assumption used in international macro theory. As already mentioned, their study reveals that capital was in fact immobile internationally. The near perfect correlation between domestic investment and saving ruled out the possibility of free inflow or outflow of capital in the OECD countries.

The initial finding by Feldstein and Horioka was followed by further studies on this issue. Explanations attempting to resolve the observed puzzle initially involved defining and measuring capital mobility using alternative approaches. Coakley et al. (1998) present two methods to measure capital mobility.

The first is the FH quantity approach in which they adopt the partial equilibrium framework used by Feldstein (1983) in order to analyze the identification problem. In this model national saving, investment and balance of payments are expressed as functions of the real interest rate and random shocks. The testing of $\mathrm{FH}$ coefficient in this model amounts to testing saving-investment correlation as well as real interest rate parity. Frankel (1991) finds that real interest rate parity does not hold for major industrialized countries and that, according to him, explains the FH coefficient. The failure of the real exchange rate parity, on the other hand could be explained by the existence of volatility of currency premium 
that results from instability of real and nominal exchange rates as claimed by Frankel(1991, 1992). Frankel also provides two definitions of perfect capital mobility other than the real exchange rate parity. These are covered interest parity and uncovered interest parity. The second approach is that of consumption smoothing.

As Coakley et al. (1998) point out, the original responses to the FH puzzle were in terms of econometric errors as the main factors guiding their result. These included identification problem, misspecification, simultaneity bias, permanent and transitory effects, sample sensitivity and non stationarity. They find the FH regression results to be robust in general and particularly so for cross section analysis. Obstfeld (1986), Baxter and Crucini (1993.) argue that OECD saving and investment data do not reflect the true values. The difference arises when the domestic firms are mostly owned by foreigners and that tends to increase the correlation coefficient between saving and investment. Other cross sectional studies like Feldstein and Bacchetta (1991) use 23 OECD countries, and also extend the number of years like in Murphy (1984), Penati and Dooley (1984), Obstfeld (1986), Obstfeld and Rogoff (1995), Coakley et al. (1994). The original FH results remain fairly undisputed in all these studies.

Some variation in studies, however, like Sinn (1992), that use less than decade averages yield coefficients less than 0.7. Another very common problem pointed out was that of saving being endogenous and the resulting simultaneity bias in the correlation coefficient. FH controlled for this problem by following an instrumental variable approach. It did not alter FH's original finding. The endogeneity issue was also put forward in the form of the 'policy reaction' argument, which is one of the most popular critiques against the FH puzzle. This argument is based on the premise that government policies designed to eliminate trade imbalances result in saving investment correlation. Taking into account the endogenous nature of savings, Sachs $(1981,1983)$ regresses current account against investment to test for a null hypothesis of unit coefficient. Frankel (1991) claims that factors producing endogeneity in savings should do the same to investment. The conclusion was that investment, national saving, and current account are all endogenous, and so the ordinary least square approach 
to the problem was put into question.

Panel data analyses of the FH puzzle by Feldstein (1983), Coakley et al (1994, 1996a, 1996) do not yield results significantly different from the original study. There are also a number of studies on the sample sensitivity of the regression. Murphy (1984) segregates his data on 17 OECD countries into two groups consisting of ten large and seven small countries and finds the coefficient to be much smaller (0.59) for small countries and much larger (0.98) for the large country group. This, he argues, is consistent with country size effect when there is capital mobility. Harberger (1980) argues that a large country is more diversified than a small country and so does not need to borrow funds from the global market. The FH coefficient thus reflects large country bias rather than capital immobility. Feldstein and Bacchetta (1991) re-examine the hypothesis of zero correlation coefficient by distinguishing between EU countries and non-EU countries. They find that using net amounts the value of the coefficient declined gradually for the EU countries till 1980 after which the decline was sharp. On the other hand the coefficient for non-EU countries declined gradually throughout. The gross measures, however, produced opposite outcomes. They concluded that capital is more mobile among EU countries.

Also studies on developing countries by Dooley et al. (1987) and Mamingi (1994) show that the saving investment coefficient is much weaker for these countries. The common argument for this is that developing countries are small open economies and thus have the country size effect. More recent studies by Miller (1988), Gundlach and Sinn (1992), Ghosh (1995), Coakley et al (1996a, 1996b), Coakley and Kulasi (1997a) focus on stationarity issues. Their general conclusion is that for both developing and OECD countries, the current account is unit root stationary or saving and investment are cointegrated. In a very recent study by Mark et al. (2004), they employ an alternative method called the dynamic seemingly unrelated cointegrating regression or DSUR in analyzing the puzzle. They, too, find the long run slope coefficients in the saving investment relation to be close to one for most countries.

The existing literature examines the FH puzzle from various perspectives. Most of the 
studies focus on empirical variations of the original finding. The main contribution of this paper is that it uses annual data on saving and investment to show that $\mathrm{FH}$ results weaken considerably towards the late 1990s and early 2000 and addresses some of the econometric issues (such as business cycle and sample sensitivity effects on estimates).

\section{Saving-Investment Correlations}

The first approach towards examining the degree of capital mobility in OECD countries uses pooled annual data on savings and investment shares of GDP from 29 OECD countries for the period 1970-2003. While the use of annual data ensures that the model considers short-term inflow and outflow of capital, it also exposes the estimates to the influences of short term output fluctuations. A proxy for business cycles is constructed following Sachs (1981). The proxy is essentially a measure of detrended GDP over the sample period for all OECD countries 1

We estimate the following regression:

$$
(I / Y)_{i t}=\gamma \cdot g d p g_{i t}+\sum_{t=1}^{34} \alpha_{t} d_{t}+\sum_{t=1}^{34} \beta_{t}(S / Y)_{i t} \cdot d_{t}+\epsilon_{i t}
$$

where, $\quad(I / Y)_{i t}=$ gross domestic investment as a share of GDP for country 'i' at time ' $\mathrm{t}$ ' $(S / Y)_{i t}=$ gross domestic savings as a share of GDP for country 'i' at time 't' $g d p g_{i t}=$ detrended GDP at constant 2000 prices for every country $i$ for each year $t$

$$
d_{t}=\text { time dummy for year ' } \mathrm{t} \text { ' }
$$

The sample period covers the years 1970-2003 and 29 OECD countries, the model thus yields thirty-four estimates of the saving-investment correlation coefficient for the OECD countries. World Development Indicators 2005 provides data on share of gross domestic savings and

\footnotetext{
${ }^{1}$ Sachs et al. (1981) use GNP gap. This paper uses GDP gap instead. To construct the business cycle proxy variable the regression $G D P_{i t}=a_{i}+b_{i} \cdot$ year $+e_{i t}$ for country "i" and year " $\mathrm{t}$ ", is estimated and the residuals are used in regression (2.1) as $g d p g$.
} 
investment 2

Table 2.1 presents the results of regression 2.1. The " $\beta$-coefficient" is the correlation between shares of domestic investment and savings in GDP. It is also referred to as the "savings retention coefficient", in Feldstein (2005). In the event of perfect capital mobility this coefficient should be equal to zero. The early seventies, as Table 2.1 shows, exhibit a very strong positive correlation between gross domestic investment and gross domestic savings as shares of GDP, with a maximum of 0.87 in 1973. This confirms the original findings by Feldstein and Horioka (1980). The retention coefficients in our regression remain positive and strong post 1970 but are now of smaller magnitudes. Throughout the 80's, the coefficients range between 0.37 in 1983 and 0.68 in 1986 . This is followed by a consistent decline in the value of the " $\beta$-coefficient" with mild fluctuations. The decline sharpens towards the end of the 90 's when there is a steep fall in the value of the retention coefficient going over to the next century. The coefficient drops consistently from a 0.54 in $1995,0.50$ in 1996 to as low as 0.23 in 1998 going down further to 0.17 in 1999 and then as low as 0.08 in 2000. The value of the retention coefficient remains close to zero till the end of the sample period. Figure 2.2.1 depicts the movement of the retention coefficient over the entire sample period.

The estimated intercept in regression (2.1) measures "gross domestic investment share in GDP" in the absence of "gross domestic savings". Figure 2.2 shows the behavior of the intercept term over the sample period. In the absence of any domestic savings, the share of investment in GDP is quite unstable. The pre-1990's is characterized by intermittent rise and fall in domestic investment (when share of savings is zero). During the 1990's the magnitudes of the intercept increase significantly. This coincides with the period which also shows a rapidly weakening saving-investment correlation. Domestic investment share reaches its peak in 1998 at $21 \%$ of GDP when domestic saving is absent.

\footnotetext{
${ }^{2} \mathrm{~A}$ description of the data set is provided in the Appendix $\mathrm{A}$
} 


\subsection{Sample Sensitivity and Robustness Tests}

The literature shows that sample sensitivity inter alia is an important issue in the context of the existence of the puzzle. Sample sensitivity tests of the above model shows that the results suggesting the disappearance of the puzzle are robust. A country by country test, as mentioned earlier in the paper, singles out any dominant effect that a country might have had on the results. A unique country is excluded at a time from the sample and regression (2.1) is estimated over and over again for each of these subsamples. The estimates in each subsample remain consistent with negligible differences with the outcomes of regression (2.1) with all OECD countries. Table 2.2 presents a comparison between the original 29 country regression and the subsample regressions, it shows the reported means and standard errors of the subsamples.

The analysis also examines but does not report, for each year, the subsample with the maximum difference with the full sample estimates. This allows one to see whether any particular country is significantly different from the rest and if that affects our initial finding. No one country proves to be particularly the driving force, however, Korea maintains the maximum departure during most of the 1990s and 2000. The estimates excluding Korea are on an average $15 \%$ less than the full sample estimates between 1990-2003. The implication is that Korea is not at par with the other OECD countries as far as financial globalization is concerned. Why is it so can be a subject of future research $3^{3}$

White's heteroscedasticity tests reject the null hypothesis of homoscedasticity of the error term that is correctd by three staged least squares method. Table 2.4 presents the results of the 3SLS procedure for the FH regression.

\footnotetext{
${ }^{3}$ The US, Greece and Portugal were expected to have some signifcant impact. The US economy, given its lion's share in the global financial market could have been crucial in the observed increase in financial integration. In a recent article Feldstein (2006) discusses how household savings in the US are really sliding down and so the country is becoming more and more dependent on the international capital market for investment funds. Blanchard and Giavazzi (2002) examine the degree of financial integration in the Euro area with special attention to the Greek and Portuguese economies. They show that both Greece and Portugal were integrated to the global financial market during the 1990s. These countries. however, have marginal impact on our results.
} 


\section{Current Account and Capital Mobility}

When current account balance responds significantly and inversely to changes in domestic investment capital is mobile internationally. For instance, if an increase in domestic investment is associated with an exact decrease in current account surplus it means that capital is moving in absolutely freely, the converse is true for a decrease in domestic investment. Thus, an alternative way to test for the perfect mobility of global capital is to look at the correlation between investment and current account balance, as used by Sachs et al. (1981). They explain the current account using investment and GNP gap. In an individual country wise analysis, they show that for developed countries there exists a negative correlation between investment and current account surplus, and that the coefficient is close to one for most countries. This suggests that current account deficits and surpluses are corrected by international capital movements.

The data used in our current account model comprises of shares of current account surplus and investment in GDP for all OECD countries leaving Czech Republic and Slovak Republic due to unavailabilty of data. We therefore estimate the following model:

$$
C A_{i t}=\gamma \cdot g d p g_{i t}+\sum_{t=1}^{34} \alpha_{t} d_{t}+\sum_{t=1}^{34} \beta_{t}(I / Y)_{i t} \cdot d_{t}+\epsilon_{i t}
$$

where, $\quad C A_{i t}=$ current account balance as a share of GDP for country $i$ at time $t$

$(I / Y)_{i t}=$ gross domestic investment as a share of GDP for country $i$ at time $t$

$g d p g_{i t}=$ detrended GDP at constant 2000 prices for every country $i$ for each year $t$

$$
d_{t}=\text { time dummy for year } t
$$

Table 2.3 presents the results of regression (2.2). The period during which S-I correlation coefficient decreases in value and approaches zero in regression (2.1), the current account-investment coefficient shows the exact opposite behavior. Not only is the correlation-

coefficient between current account balance and investment negative and approaches negative 
one over this period, also investment is found to be a significant determinant of current account balance as well. The coefficient changes from -0.05 in 1995 to -0.24 in 1997 to -0.49 in 1999 and -0.68 in 2000. Thus investment becomes increasingly important in determining current account balance. A current account deficit is accompanied by inflow of foreign capital. This provides further evidence in support of the increasing global capital mobility towards the end of the last century and beginning of the present.

Conventional theory suggests that an increase in GDP should lead to greater import demand which in turn magnifies trade deficit. Accordingly, the coefficient of $g d p g$ in regression (2.2) should be negative. Our results show that the $g d p g$ coefficient is -9.14 , which is both negative and significant.

Figure 2.3 presents the S-I correlation coefficient as well as the current account-investment correlation coefficient for all OECD members. It is clear that the period over which the S-I coefficient declines sharply and almost approaches zero, the CA-I coefficient declines too and approaches negative one.

Table 2.4 presents the results of the 3SLS procedure for regression $(2.2)$ along with the 3SLS results for regression 2.1.

\section{Developing Countries}

The analysis so far implies that international financial integration is indeed strengthened towards the late 1990s as far as developed countries are concerned. However, in order to ascribe a global status to this observed phenomenon it is necessary to study the developing countries. Did developing countries also become financially integrated during this time?

FH regressions are estimated with 61 developing countries for every year between 1970 and 2003. Table 2.5 presents the regression results for developing countries. As the table depicts and as earlier research shows, developing countries started off with a much lower savings retention coefficient than the developed countries. The coefficient for developing 
countries continue to decline thereafter bearing evidence to huge inflow of foreign capital in these countries, especially during 1973-81.

The evidence on developing countries suggests that these countries have been financially more open all along the sample period. The decrease in the magnitude of the coefficient has started much earlier and has been more gradual and consistent for the developing countries as compared to the OECD countries. Figure 2.4 shows a graphical representation of this phenomenon. The graph shows that after the sharp fall in the value of the coefficient for the OECD countries the two sets of countries appear to move towards convergence. Financial globalization hence appears to be truly global. At the same time it also indicates that major changes post 1995 have remained somewhat confined to the developed nations. Developing countries start off with a higher degree of financial integration but have made a gradual progress towards improving it and finally converging with the rich nations. Developed countries, on the other hand, seem to have started off a bit late but proceeded with remarkable pace towards international integration of capital markets.

\section{Conclusion}

The Feldstein-Horioka puzzle has mystified international macroeconomics for over a decade. The analysis with recent data implies that the puzzle is on the verge of disappearance. Sample sensitivity tests for individual country effects verify whether the apparent increase in global capital mobility is truly so. The purpose of this study is to provide evidences in support of the phenomenal growth in financial globalization. Accounting for the factors responsible for this is something beyond the scope of this paper but will certainly be an issue for future research.

Our plans for further research in this area aim at but are not confined to identifying various components of world capital that have been globalized. Distinguishing between FDI and portfolio investment as well as foreign aid in case of developing countries has the 
potential of generating useful and interesting results in the context of financial integration. Examination and analysis of government policy and institutional issues become imperative in this regard. 
Figure 2.1: S-I Correlation Coefficient for OECD Countries

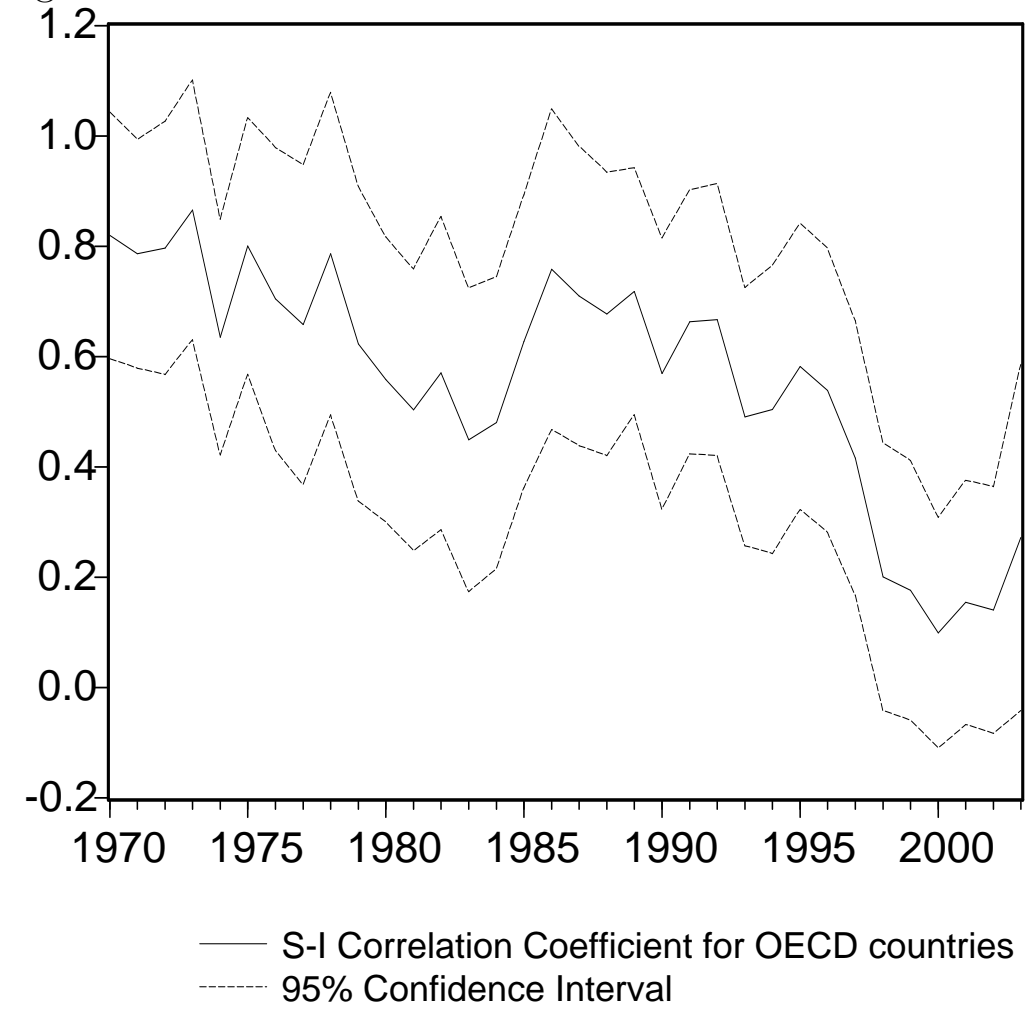

Figure 2.2: The Intercept

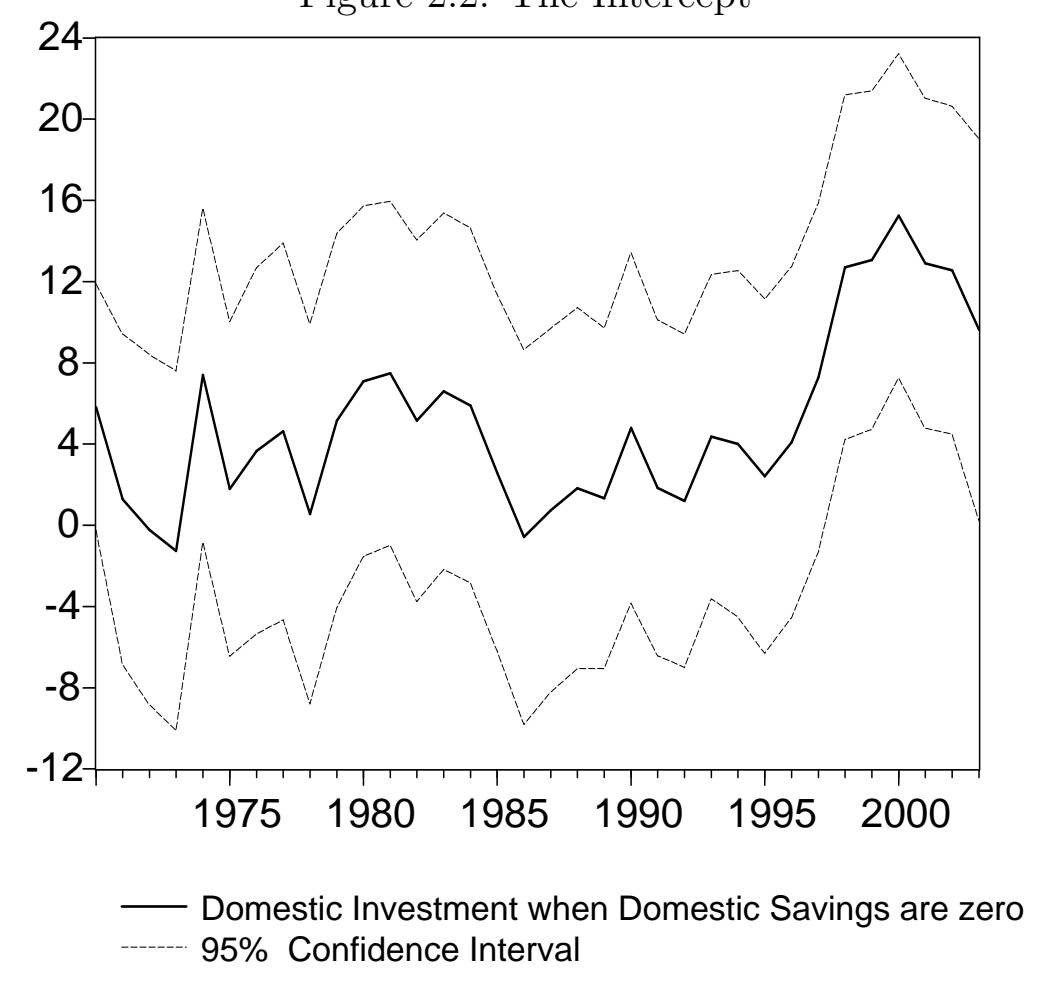


Figure 2.3: Current Account-Investment and S-I Correlations

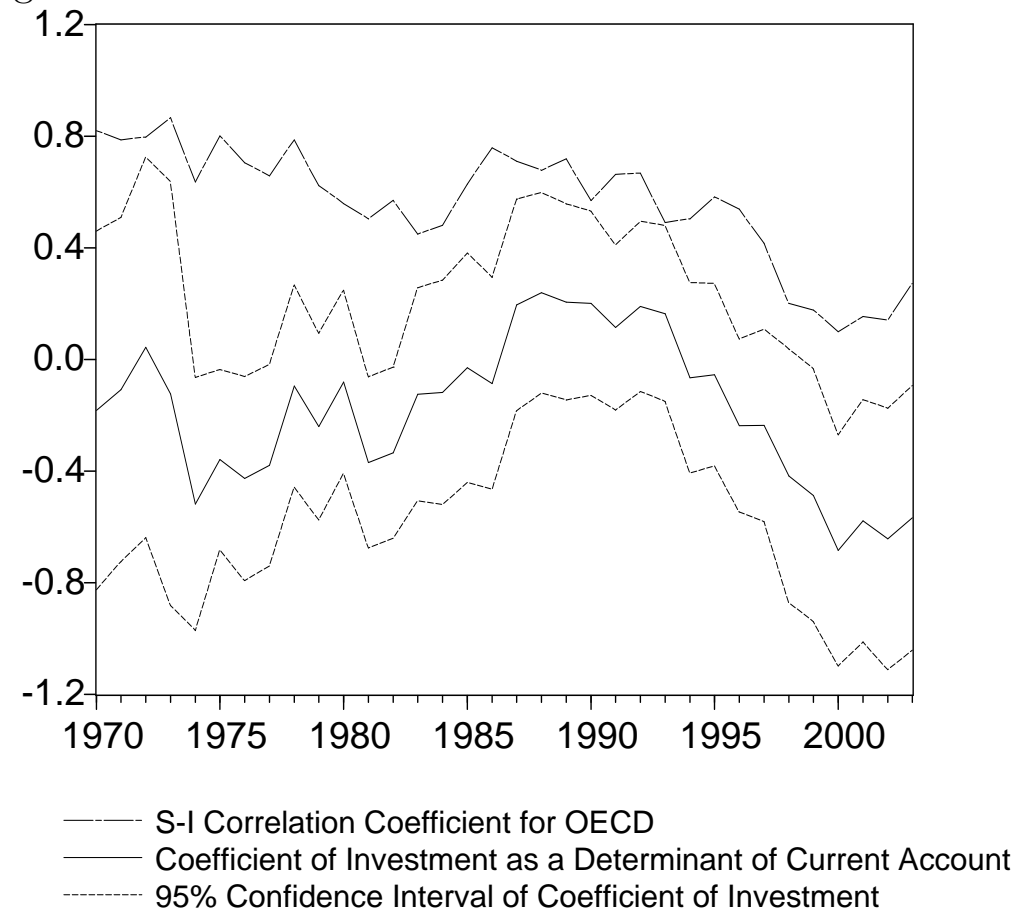

Figure 2.4: S-I Correlations for OECD and Developing Countries

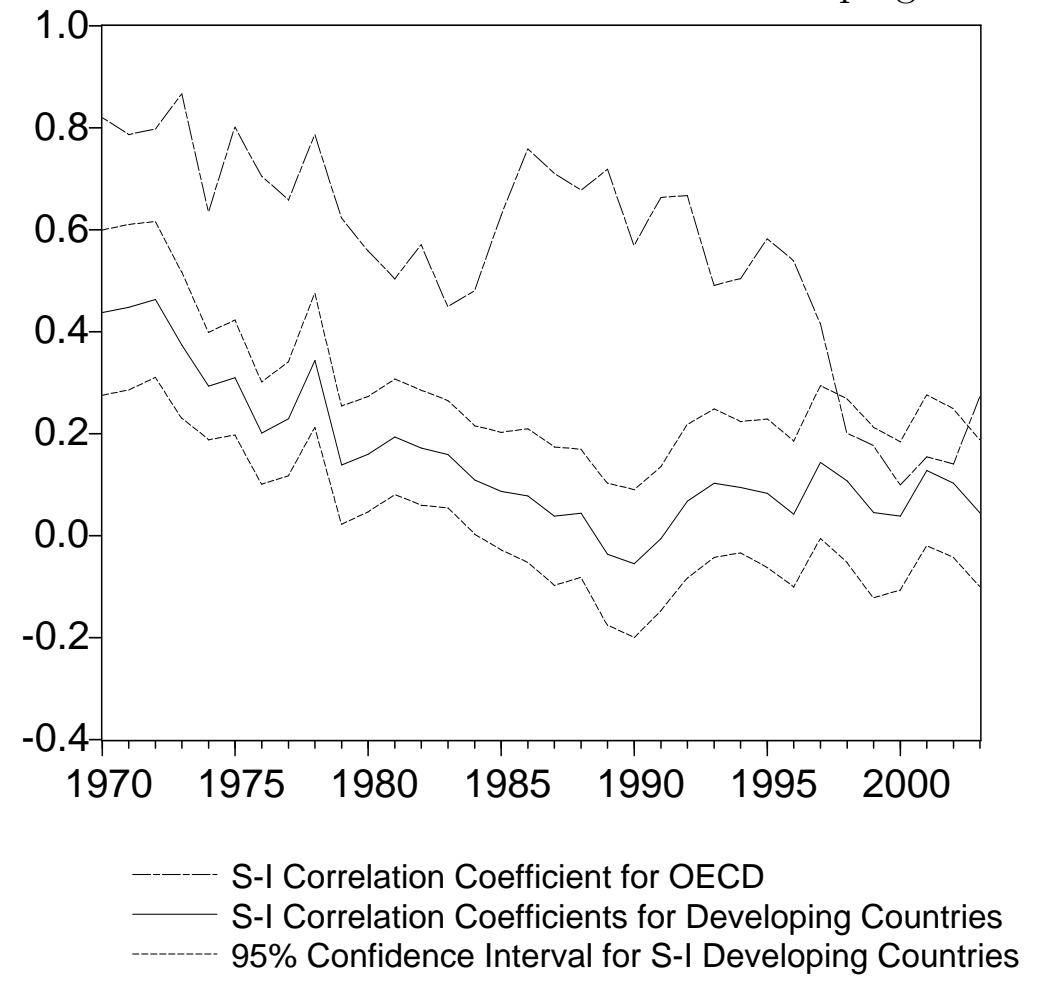


Table 2.1: Saving Investment Correlation Coefficients for 29 OECD Countries Dependent Variable:Investment

\begin{tabular}{cccccccccc}
\hline \hline Year & Intercept & S.E. & $\hat{\beta}$ & S.E. & Year & Intercept & S.E. & $\hat{\beta}$ & S.E. \\
\hline 1970 & 6.3418 & 3.0826 & 0.8477 & 0.1148 & 1988 & 3.0355 & 4.6743 & 0.5856 & 0.1415 \\
1971 & 0.7692 & 4.1417 & 0.8200 & 0.1063 & 1989 & 2.5705 & 4.6607 & 0.6245 & 0.1400 \\
1972 & -0.8941 & 4.3865 & 0.8196 & 0.1176 & 1990 & 5.4735 & 4.3965 & 0.5006 & 0.1255 \\
1973 & -2.1273 & 4.4999 & 0.8718 & 0.1196 & 1991 & 2.6268 & 4.2135 & 0.6072 & 0.1220 \\
1974 & 6.4801 & 4.1771 & 0.6477 & 0.1083 & 1992 & 2.4893 & 4.1755 & 0.5969 & 0.1255 \\
1975 & 0.9906 & 4.1832 & 0.8199 & 0.1181 & 1993 & 5.9429 & 4.0629 & 0.4191 & 0.1191 \\
1976 & 2.1997 & 4.5816 & 0.7371 & 0.1393 & 1994 & 4.7891 & 4.3420 & 0.4637 & 0.1327 \\
1977 & 3.3735 & 4.7164 & 0.6776 & 0.1467 & 1995 & 3.2636 & 4.4407 & 0.5399 & 0.1321 \\
1978 & -0.7805 & 4.7517 & 0.8038 & 0.1484 & 1996 & 4.6709 & 4.3972 & 0.5049 & 0.1307 \\
1979 & 4.5738 & 4.6847 & 0.6043 & 0.1453 & 1997 & 7.2484 & 4.3723 & 0.4000 & 0.1263 \\
1980 & 7.5505 & 4.3816 & 0.4952 & 0.1317 & 1998 & 11.5984 & 4.3225 & 0.2265 & 0.1232 \\
1981 & 8.2452 & 4.3035 & 0.4285 & 0.1303 & 1999 & 12.5448 & 4.2385 & 0.1732 & 0.1195 \\
1982 & 6.5871 & 4.5334 & 0.4794 & 0.1447 & 2000 & 14.9018 & 4.0651 & 0.0829 & 0.1063 \\
1983 & 7.9166 & 4.4607 & 0.3679 & 0.1401 & 2001 & 13.0160 & 4.1323 & 0.1225 & 0.1122 \\
1984 & 6.8747 & 4.4375 & 0.4094 & 0.1344 & 2002 & 12.8096 & 4.1064 & 0.1019 & 0.1136 \\
1985 & 3.6105 & 4.5017 & 0.5506 & 0.1385 & 2003 & 8.2932 & 4.7802 & 0.3230 & 0.1591 \\
1986 & 0.4549 & 4.7693 & 0.6821 & 0.1536 & & & & & \\
1987 & 1.5273 & 4.6386 & 0.6419 & 0.1448 & gdpg & 16.2771 & 2.5931 & & \\
\hline
\end{tabular}

The estimates Intercept and $\hat{\beta}$ measure respectively the constant and the saving-investment correlation coefficient from the regression $(I / Y)_{i t}=\gamma \cdot g d p g_{i t}+\sum_{t=1}^{34} \alpha_{t} d_{t}+\sum_{t=1}^{34} \beta_{t}(S / Y)_{i t} \cdot d_{t}+\epsilon_{i t}$ The variable $g d p g$ is a proxy accounting for short term business cycle effects. 
Table 2.2: Full Sample vs. Subsample Estimates

\begin{tabular}{llll|llll}
\hline \hline Year & AllOECD & SubMean & \multicolumn{1}{l}{ SubSE } & Year & AllOECD & SubMean & SubSE \\
\hline 1970 & 0.8477 & 0.8386 & 0.0236 & 1987 & 0.6419 & 0.6491 & 0.0262 \\
1971 & 0.8197 & 0.8062 & 0.0219 & 1988 & 0.5856 & 0.5951 & 0.0225 \\
1972 & 0.8195 & 0.8023 & 0.0129 & 1989 & 0.6245 & 0.6284 & 0.0245 \\
1973 & 0.8718 & 0.8695 & 0.0183 & 1990 & 0.5006 & 0.5038 & 0.0332 \\
1974 & 0.6477 & 0.6473 & 0.0268 & 1991 & 0.6072 & 0.6078 & 0.0377 \\
1975 & 0.8199 & 0.8127 & 0.0302 & 1992 & 0.5969 & 0.5970 & 0.0330 \\
1976 & 0.7372 & 0.7339 & 0.0348 & 1993 & 0.4192 & 0.4223 & 0.0357 \\
1977 & 0.6776 & 0.6782 & 0.0330 & 1994 & 0.4637 & 0.4598 & 0.0406 \\
1978 & 0.8038 & 0.8053 & 0.0402 & 1995 & 0.5399 & 0.5373 & 0.0465 \\
1979 & 0.6043 & 0.6014 & 0.0536 & 1996 & 0.5049 & 0.5053 & 0.0503 \\
1980 & 0.4952 & 0.5007 & 0.0340 & 1997 & 0.4000 & 0.3989 & 0.0395 \\
1981 & 0.4285 & 0.4434 & 0.0362 & 1998 & 0.2265 & 0.2235 & 0.0177 \\
1982 & 0.4794 & 0.4807 & 0.0260 & 1999 & 0.1732 & 0.1708 & 0.0264 \\
1983 & 0.3679 & 0.3751 & 0.0283 & 2000 & 0.0829 & 0.0871 & 0.0269 \\
1984 & 0.4094 & 0.4159 & 0.0227 & 2001 & 0.1225 & 0.1242 & 0.0288 \\
1985 & 0.5506 & 0.5512 & 0.0252 & 2002 & 0.1019 & 0.1011 & 0.0323 \\
1986 & 0.6821 & 0.6842 & 0.0204 & 2003 & 0.3231 & 0.3205 & 0.0497 \\
\hline
\end{tabular}

Columns AllOECD show the estimates from the regression $(I / Y)_{i t}=\gamma \cdot g d p g_{i t}+\sum_{t=1}^{34} \alpha_{t} d_{t}+$ $\sum_{t=1}^{34} \beta_{t}(S / Y)_{i t} \cdot d_{t}+\epsilon_{i t}$ for all OECD countries. Columns SubMean present the mean of the subsample estimates for each year. Each subsample has a unique country missing from the full sample of 29 OECD countries. Columns SubSE show the standard errors of the subsamples for every year. 
Table 2.3: Current Account Approach to the FH puzzle

Dependent Variable: Current Account Balance

\begin{tabular}{ccrrr|rrrrc}
\hline \hline Year & Intercept & \multicolumn{1}{c}{ S.E. } & Invest & \multicolumn{1}{c}{ S.E. } & Year & Intercept & S.E. & Invest & S.E. \\
\hline 1970 & 4.2567 & 8.0512 & -0.1826 & 0.3276 & 1988 & -10.3213 & 9.1810 & 0.2388 & 0.1831 \\
1971 & -1.4967 & 11.3440 & -0.1079 & 0.3146 & 1989 & -10.0062 & 9.1863 & 0.2056 & 0.1793 \\
1972 & -4.6723 & 11.7392 & 0.0432 & 0.3474 & 1990 & -9.6469 & 9.0350 & 0.2007 & 0.1684 \\
1973 & -0.5632 & 12.8410 & -0.1231 & 0.3871 & 1991 & -7.7396 & 8.7550 & 0.1143 & 0.1511 \\
1974 & 6.5991 & 10.0700 & -0.5178 & 0.2311 & 1992 & -9.2453 & 8.7134 & 0.1896 & 0.1555 \\
1975 & 2.3842 & 9.0508 & -0.3587 & 0.1647 & 1993 & -8.3940 & 8.7148 & 0.1643 & 0.1610 \\
1976 & 4.3055 & 9.4244 & -0.4264 & 0.1865 & 1994 & -3.2505 & 8.8532 & -0.0658 & 0.1743 \\
1977 & 3.5205 & 9.3758 & -0.3786 & 0.1841 & 1995 & -2.8898 & 8.8319 & -0.0547 & 0.1666 \\
1978 & -2.7080 & 9.2699 & -0.0949 & 0.1843 & 1996 & 0.8474 & 8.7745 & -0.2365 & 0.1582 \\
1979 & 0.2859 & 9.1798 & -0.2402 & 0.1705 & 1997 & 1.2405 & 8.9813 & -0.2365 & 0.1757 \\
1980 & -4.7139 & 9.1507 & -0.0804 & 0.1677 & 1998 & 5.1804 & 9.6531 & -0.4172 & 0.2321 \\
1981 & 1.8354 & 8.9334 & -0.3687 & 0.1562 & 1999 & 6.1695 & 9.6430 & -0.4867 & 0.2309 \\
1982 & 1.2976 & 8.8853 & -0.3338 & 0.1561 & 2000 & 11.0290 & 9.4540 & -0.6841 & 0.2112 \\
1983 & -2.5516 & 9.1945 & -0.1250 & 0.1949 & 2001 & 8.5810 & 9.4215 & -0.5779 & 0.2213 \\
1984 & -2.4077 & 9.3410 & -0.1180 & 0.2050 & 2002 & 9.5135 & 9.5350 & -0.6428 & 0.2386 \\
1985 & -4.5070 & 9.3662 & -0.0291 & 0.2095 & 2003 & 8.0586 & 9.5724 & -0.5672 & 0.2419 \\
1986 & -3.1324 & 9.1851 & -0.0862 & 0.1937 & & & & & \\
1987 & -9.196 & 9.2112 & 0.1954 & 0.1935 & $g d p g$ & -9.1375 & 3.3810 & & \\
\hline
\end{tabular}

The estimates Invest measure the coefficient of Investment in the regression $C A_{i t}=\gamma \cdot g d p g_{i t}+\sum_{t=1}^{34} \alpha_{t} d_{t}+$ $\sum_{t=1}^{34} \beta_{t}(I / Y)_{i t} \cdot d_{t}+\epsilon_{i t}$. The estimate $g d p g$ measures the coefficient of the proxy for short term output fluctuations in the same regression. It is estimated to be -9.14 (S.E. 3.38). 
Table 2.4: FH Approach vs. Current Account Approach

Dependent Variables: Investment and Current Account Balance

\begin{tabular}{cccccccccc}
\hline \hline Year & $\hat{\beta}_{F H}$ & S.E. & $\hat{\beta}_{C A}$ & \multicolumn{1}{c}{ S.E. } & Year & $\hat{\beta}_{F H}$ & S.E. & $\hat{\beta}_{C A}$ & S.E. \\
\hline 1970 & 0.8477 & 0.1148 & -0.1826 & 0.3276 & 1988 & 0.5856 & 0.1415 & 0.2388 & 0.1831 \\
1971 & 0.8197 & 0.1063 & -0.1079 & 0.3146 & 1989 & 0.6245 & 0.1400 & 0.2056 & 0.1793 \\
1972 & 0.8195 & 0.1176 & 0.0432 & 0.3474 & 1990 & 0.5006 & 0.1255 & 0.2007 & 0.1684 \\
1973 & 0.8718 & 0.1196 & -0.1231 & 0.3871 & 1991 & 0.6072 & 0.1220 & 0.1143 & 0.1511 \\
1974 & 0.6477 & 0.1083 & -0.5179 & 0.2311 & 1992 & 0.5969 & 0.1255 & 0.1896 & 0.1555 \\
1975 & 0.8199 & 0.1181 & -0.3587 & 0.1647 & 1993 & 0.4192 & 0.1191 & 0.1644 & 0.1610 \\
1976 & 0.737 & 0.1393 & -0.4264 & 0.1865 & 1994 & 0.4637 & 0.1327 & -0.0658 & 0.1743 \\
1977 & 0.6776 & 0.1467 & -0.3786 & 0.1841 & 1995 & 0.5399 & 0.1321 & -0.0547 & 0.1666 \\
1978 & 0.8038 & 0.1484 & -0.0949 & 0.1843 & 1996 & 0.5049 & 0.1307 & -0.2365 & 0.1582 \\
1979 & 0.6043 & 0.1453 & -0.2402 & 0.1705 & 1997 & 0.4000 & 0.1263 & -0.2365 & 0.1757 \\
1980 & 0.4952 & 0.1317 & -0.0804 & 0.1677 & 1998 & 0.2265 & 0.1232 & -0.4172 & 0.2321 \\
1981 & 0.4285 & 0.1303 & -0.3687 & 0.1562 & 1999 & 0.1732 & 0.1195 & -0.4867 & 0.2309 \\
1982 & 0.4794 & 0.1447 & -0.3338 & 0.1561 & 2000 & 0.0829 & 0.1063 & -0.6841 & 0.2112 \\
1983 & 0.3679 & 0.1401 & -0.1250 & 0.1949 & 2001 & 0.1225 & 0.1122 & -0.5779 & 0.2213 \\
1984 & 0.4094 & 0.1344 & -0.1180 & 0.2050 & 2002 & 0.1019 & 0.1136 & -0.6428 & 0.2386 \\
1985 & 0.5506 & 0.1385 & -0.0291 & 0.2095 & 2003 & 0.3231 & 0.1591 & -0.5672 & 0.2419 \\
1986 & 0.6821 & 0.1536 & -0.0862 & 0.1937 & & & & & \\
1987 & 0.6419 & 0.1448 & 0.1954 & 0.1935 & $g d p g$ & 16.2771 & 2.5931 & -9.1375 & 3.3810 \\
\hline
\end{tabular}

The estimates $\hat{\beta}_{F H}$ measure the saving-investment correlation coefficient for all OECD countries from the 3SLS regression $(I / Y)_{i t}=\gamma \cdot g d p g_{i t}+\sum_{t=1}^{34} \alpha_{t} d_{t}+\sum_{t=1}^{34} \beta_{t}(S / Y)_{i t} \cdot d_{t}+\epsilon_{i t}$. The estimates $\hat{\beta}_{C A}$ measure the coefficient of investment for all OECD countries in the 3SLS regression $C A_{i t}=\gamma \cdot g d p g_{i t}+\sum_{t=1}^{34} \alpha_{t} d_{t}+$ $\sum_{t=1}^{34} \beta_{t}(I / Y)_{i t} \cdot d_{t}+\epsilon_{i t}$. 
Table 2.5: FH-Coefficient for Developing Countries

Dependent Variable: Investment

\begin{tabular}{ccclc|ccccc}
\hline \hline Year & Intercept & S.E. & $\hat{\beta}_{\text {developing }}$ & S.E. & Year & Intercept & S.E. & $\hat{\beta}_{\text {developing }}$ & S.E. \\
\hline 1970 & 11.2140 & 1.5832 & 0.4375 & 0.0826 & 1988 & 8.7974 & 2.0523 & 0.0437 & 0.0640 \\
1971 & 0.9109 & 2.2154 & 0.4476 & 0.0828 & 1989 & 9.5609 & 2.1103 & -0.0369 & 0.0710 \\
1972 & 0.7357 & 2.1845 & 0.4643 & 0.0779 & 1990 & 10.087 & 2.1511 & -0.0557 & 0.0741 \\
1973 & 2.2639 & 2.2094 & 0.3727 & 0.0732 & 1991 & 9.5202 & 2.1044 & -0.0064 & 0.0720 \\
1974 & 4.9909 & 2.0854 & 0.2930 & 0.0537 & 1992 & 8.8218 & 2.0996 & 0.0674 & 0.0766 \\
1975 & 7.1984 & 2.0361 & 0.3124 & 0.0575 & 1993 & 8.7124 & 2.0703 & 0.1028 & 0.0744 \\
1976 & 8.6301 & 2.0109 & 0.2039 & 0.0512 & 1994 & 9.0699 & 2.0523 & 0.0989 & 0.0659 \\
1977 & 8.5035 & 2.0731 & 0.2311 & 0.0571 & 1995 & 9.7421 & 2.1486 & 0.0844 & 0.0743 \\
1978 & 7.5011 & 2.1415 & 0.3448 & 0.0672 & 1996 & 9.8659 & 2.1568 & 0.0438 & 0.0730 \\
1979 & 9.8674 & 2.0695 & 0.1386 & 0.0591 & 1997 & 8.1767 & 2.1748 & 0.1440 & 0.0763 \\
1980 & 9.5216 & 2.0438 & 0.1593 & 0.0577 & 1998 & 8.9574 & 2.1962 & 0.1071 & 0.0818 \\
1981 & 9.7138 & 2.0000 & 0.1939 & 0.0578 & 1999 & 8.5690 & 2.2314 & 0.0432 & 0.0852 \\
1982 & 9.3869 & 1.9934 & 0.1718 & 0.0576 & 2000 & 8.7961 & 2.1872 & 0.0367 & 0.0741 \\
1983 & 7.4210 & 1.9710 & 0.1595 & 0.0535 & 2001 & 7.5715 & 2.1878 & 0.1260 & 0.0755 \\
1984 & 7.0184 & 1.9882 & 0.1095 & 0.0543 & 2002 & 7.1032 & 2.1442 & 0.1006 & 0.0743 \\
1985 & 7.7470 & 2.0034 & 0.0876 & 0.0587 & 2003 & 8.6546 & 2.1603 & 0.0425 & 0.0735 \\
1986 & 7.7110 & 2.0508 & 0.0781 & 0.0669 & & & & & \\
1987 & 7.9287 & 2.0669 & 0.0378 & 0.0692 & gdpg & -1.0355 & 1.1447 & & \\
\hline
\end{tabular}

The estimates Intercept and $\hat{\beta}_{\text {developing }}$ measure respectively the constant and the saving-investment correlation coefficient in the regression $(I / Y)_{i t}=\gamma \cdot g d p g_{i t}+\sum_{t=1}^{34} \alpha_{t} d_{t}+\sum_{t=1}^{34} \beta_{t}(S / Y)_{i t} \cdot d_{t}+\epsilon_{i t}$ for developing countries. The variable $g d p g$ is a proxy for short term output fluctuations. 


\section{Chapter 3}

\section{Outsourcing and Domestic Tax Policy}

\section{Introduction}

The recent surge of job outsourcing from developed to developing countries has sparked off active research in this area. The phenomenon of outsourcing is not a new development in this era of globalization; it is its changing nature that has triggered much controversy in

recent economic literature. A popular area of discussion has been the negative impact of job outsourcing on labor market in the source country.

Most of existing work in this area focus on wage and productivity effects of foreign outsourcing. This paper aims at analyzing the effect of international outsourcing on labor and profit income taxes in the home country. A political equilibrium model following Razin et al. (2002), in which they have analyzed the effect of immigration on the burden of labor income tax, reveals that an increase in low skilled foreign outsourcing reduces the burden of labor tax rates in the domestic economy while increasing profit tax rates.

The model includes two types of workers, namely managers or high skilled workers who also own the firms and workers who are low skilled and are hired by the managers. An individual can choose to become either of the two given his innate ability and the cost of acquiring skills. In addition, we also introduce outsourcing as a factor in a firm's decision 
making. The firms or managers can hire native workers and outsource jobs abroad. The government taxes both labor income and profit income and provides transfers. The tax rates are determined through a process of voting in which the median voter plays a pivotal role. Our model shows that if the domestic firms increase foreign outsourcing, labor tax rates decline and profit tax rates increase unambiguously in the home country.

The paper is structured as follows. Section 2 provides a brief review of related literature. Section 3 presents a political equilibrium model to show the effect of outsourcing on labor and profit income tax rates. Section 4 presents some concluding remarks and policy implications.

\section{Related Literature}

The model developed in this paper is related to Razin et al. (2002), Saint-Paul (1994), and Eeckhout and Jovanovic (2007). We use the median voter model from Razin et al. (2002) to determine optimal tax rates and then analyze the impact of those of foreign outsourcing. While Razin et al. (2002) focuses on the the impact of immigration on the determination of the domestic income tax rate under majority voting, we examine the effect of outsourcing. We will later compare our results to those in Razin et al. (2002). The distinction between two categories of labor, namely managers and workers is based on the literature on occupational choice and globalization. Few studies such as Eeckhout and Jovanovic (2007), Antrás et al. (2006), Kremer and Maskin (2003) analyze the effect of foreign outsourcing on domestic wages in the presence of occupational choice. While all these studies implicitly or explicitly use the manager-worker theory, our model most closely related to Eeckhout and Jovanovic (2007). They claim that with increased outourcing of low skilled activities there is a shift in ocupational choice in the outsourcing countries where the labor force icnreasingly choose to become managers and hence move up the income scale. We extend their study by incorporating both labor and profit taxes into the model. Our finding that an increase in outsourcing induces the median voter to vote for lower labor taxes supports their theory that 
exporting low skilled tasks to labor abundant low income countries raises the proportion of managers in the domestic labor market and hence the real income. As a result they vote for lower labor taxes. Profit taxes, on the other hand, increase, creating incentives for a part of the labor force to become workers.

There are several other studies that relate outsourcing with relative wages of skilled and unskilled workers in the domestic economy. The popular view is that increase in outsourcing increases the relative wages of the skilled labor force.

International outsourcing leads to an outward shift in the relative demand curve for labor, which in turn affects the relative wage. Feenstra and Hanson (1996) consider two countries, skill-abundant-North and non-skill-abundant-South differing in wages. If North manufactures intermediate inputs at a lower cost in South using unskilled labor, North would then specialize in skilled goods. This would increase the demand for skilled labor in North and raise the relative wage of skilled labor. Anderton and Brenton (1997) study the data on UK's manufacturing sector and measure outsourcing as the volume of imports from low wage economies. They estimate that 'low wage imports' accounted for 40 percent of income increase of high skilled workers in UK during the period 1970-83. They also find that the imports accounted for one-third of the increase in employment of skilled labor. Head and Ries (2000) study the Japanese economy and find a very strong positive correlation between the change in a firm's skilled wage share and the change in the share of low wage foreign employment of the same firm. Over the last two decades Hong Kong has been sharing its production process with China. Hsieh and Woo (1999) find a positive correlation between Hong Kong's outsourcing and its demand for skilled labor between 1981 and 1996. They also find that during the same period there was strong direct relationship between imports from China and the share of skilled wages in Hong Kong, further supporting the theory. 


\section{The Model}

Consider an economy populated by individuals characterized by their innate ability $e$ : a lower level of $e$ indicates a lower cost of acquiring education. $e$ follows a uniform distribution on the interval $[0,1]$. Individuals are endowed with one unit of labor time and decide whether to invest in education or not. Those that receive education become managers, while those that do not invest in education become unskilled workers 1

\subsection{Firm's Problem and Occupational Choice}

Each firm produces output $q$ with the input of a manager and a set of workers. The production function is given by $q=F(H)$, where $H$ is the total number of workers employed by the firm, $F^{\prime}>0$ and $F^{\prime \prime}<02$ A manager pays a wage $w$ per unit of labor hired. The manager owns the firm and receives the firm's profits $3^{3}$

Additionally, the country has access to the international labor market. Specifically, suppose that each domestic firm has access to units of labor at wage, both taken as exogenously given. is in this case a predetermined policy variable.

Individuals pay taxes: workers pay a labor income tax, with tax rate $t$, and managers pay a tax on the income they receive, with tax rate $\tau$. The latter is essentially a profit tax. The cost of acquiring skills is given by $\gamma e$, where $\gamma>0$. Education costs are not tax deductible. Total taxes collected by the government, denoted with a $T$, are uniformly distributed back to the population. 4

On one hand, an individual with innate ability $e$ that invests in education and becomes

\footnotetext{
${ }^{1}$ To simplify the analysis, we assume that managers and unskilled workers are ex-post identical.

${ }^{2}$ It could also be assumed that the production function depends on the manager skill level, i.e., $q=$ $(1-e) F(H)$.

${ }^{3}$ In Razin et al. (2002), the production function is assumed to exhibit CRS and factors of production are perfectly substitutable. Factor prices are also given. Specifically, the production function is defined as $F(L, K)=w L+(1+r) K$, where $w$ is the wage rate and $(1+r)$ is the gross rental price of capital. Moreover, the tax rate on labor capital income is assumed to be the same.

${ }^{4}$ Since the total population has measure one, then each individual receives $T$.
} 
a manager would earn $N(w, \tau)-,\gamma e+T$, where

$$
\begin{aligned}
N(w, \tau,) & \equiv \max _{\{h\}}\{\pi(h,)(1-\tau)\}, \\
& \equiv \max _{\{h\}}\{[F(H)-w h-](1-\tau)\}
\end{aligned}
$$

and $h$ is the number of domestic workers hired by the firm. The manager can employ domestic labor or foreign labor to satisfy the total demand for labor of the firm, i.e., $H=h+$. As long as in equilibrium $w>$ (which is the case that we will consider in this paper), the FOC

$$
F^{\prime}(H)-w=0
$$

implicitly defines the demand for labor for each manager, denoted by $H(w) !^{5}$ On the other hand, an individual characterized by $e$ would earn $w(1-t)+T$ as an unskilled worker.

Assuming that individuals only care about the level of consumption or total disposable income, then there exist a critical level of $e$, , for which individuals with $e<$ become managers, and $e>$ remain unskilled. In other words, the set of managers is defined by

$$
M(w, t, \tau,) \equiv\{e \in[0,1]: N(w, \tau,)-\gamma e>w(1-t)\}
$$

and the set of workers $W$ is simply the complement of this set.

Once occupations are determined, it is possible to obtain the government's tax revenue:

$$
T(w,, t, \tau,) \equiv \tau \pi(w,)+(1-) t w
$$

\footnotetext{
${ }^{5}$ Since we assumed that managers are ex-post identical, then they will all demand the same amount of labor.
} 


\subsection{Equilibrium}

A market equilibrium is given by values $\{w$,$\} such that$

$$
\begin{aligned}
N(w, \tau,)-\gamma+T(w,, t, \tau,) & =w(1-t)+T(w,, t, \tau,), \\
H(w) & =(1-)+
\end{aligned}
$$

as long as in equilibrium $h(w)>0($ or $H(w)->0)$, so that $w>$. Equation (3.5) summarizes the occupational decisions made by the population: it defines the value of $e$ for which income as a manager is equal to labor income. Equation (3.6) simply establishes that $w$ is such that labor demand is equal to labor supply. These two equations define $(t, \tau$,$) and w(t, \tau$,$) .$

\subsection{Comparative static results}

We now examine how both and are affected by changes in $t, \tau$, and . Differentiating the system of equations (3.5)-(3.6) with respect to $t$, we obtain the following results:

$$
\begin{aligned}
\frac{\partial w}{\partial t} & =-\frac{1}{\Delta} w(h+1)>0, \\
\frac{\partial}{\partial t} & =\frac{1}{\Delta} \frac{w}{F^{\prime \prime}}>0,
\end{aligned}
$$

where

$$
\Delta=-[h(1-\tau)+(1-t)](h+1)+\gamma / F^{\prime \prime}<0,
$$

and $h(w)=H(w)-$. A higher level of $t$, for a given level of $w$, encourages individuals to become managers, i.e., increases. As the number of managers gets larger, the relative compensation of workers rises as well. Higher relative wages makes managerial work less attractive, but still the value of is higher than the original one, with a lower labor tax rate. 
Similarly, differentiating the system with respect to $\tau$ :

$$
\begin{aligned}
\frac{\partial w}{\partial \tau} & =\frac{1}{\Delta} \pi(h+1)<0 \\
\frac{\partial}{\partial \tau} & =-\frac{1}{\Delta} \frac{\pi}{F^{\prime \prime}}<0 .
\end{aligned}
$$

A higher profit tax rate negatively affects and .

Finally, the comparative static results with respect to can be written as

$$
\begin{aligned}
\frac{\partial w}{\partial} & =-\frac{1}{\Delta}(1-\tau)(w-)(h+1)>0, \\
\frac{\partial}{\partial} & =\frac{1}{\Delta} \frac{(1-\tau)(w-)}{F^{\prime \prime}}>0 .
\end{aligned}
$$

More outsourcing raises firms' profits, making managerial work more attractive. As a result, increases. Since the supply of domestic labor declines, and since we consider an equilibrium where $h>0$, then wages should increase, as shown in 3.10.

\section{Tax rates}

In this section, we derive the optimal tax rates for each group of individuals: managers and workers. Individuals only care about the level of consumption or total disposable income. Let $c(e, t, \tau$,$) denote the consumption level of an individual with ability e$. This function is strictly decreasing in the innate ability parameter for managers and constant for unskilled workers:

$$
c(e, t, \tau,)= \begin{cases}N(w, \tau,)-\gamma e+T(w,, t, \tau,), & \text { if } 0 \leq e \leq(t, \tau,) \\ w(1-t)+T(w, t, \tau,), & \text { if }(t, \tau,)<e \leq 1\end{cases}
$$

In what follows, we assume that tax rates are determined by majority voting. Our objective consists on deriving the equilibrium level of each one of the tax rates for a given 
level of the other one. In this way, we avoid the problems created by multidimensional voting, in this case, voting on two tax rates.

\subsection{Labor tax rate}

Since the tax rate $t$ is determined by majority voting, we should determine whether the median voter is the one deciding the outcome of the political process. Managers and workers choose their preferred labor tax rate by maximizing (3.11) with respect to $t$, i.e.,

$$
\frac{\partial c(e, t, \tau,)}{\partial t} \equiv B(t, \tau,)=0
$$

As individuals within each group (managers and workers) are ex-post identical, then they will choose the same tax rate. Specifically, all $e \in M$ choose the same tax rate, denoted $t^{m}$, and all $e \in W$ choose $t^{w}$ [ Under these conditions, the median voter becomes crucial in determining the outcome of majority voting. Thus, the political equilibrium tax rate may be obtained by maximizing the consumption of the median voter. The median voter, however, can either belong to the group of managers or to the group of workers, so both alternatives should be considered.

Given that the distribution of the ability parameter is uniform and that the population is normalized to 1 , the median voter is an individual with $=1 / 2$. Thus, we can now substitute $e=1 / 2$ and derive the consumption of the median voter when the median voter is a manager, $\in M$, and when the median voter is a worker,$\in W$. The objective functions are, respectively, given by

$$
c(, t, \tau,)= \begin{cases}N(w, \tau,)-\gamma / 2+T(w,, t, \tau,), & \text { if } 0 \leq \leq(t, \tau) \\ w(1-t)+T(w, t, \tau,), & \text { if }(t, \tau,)<\leq 1\end{cases}
$$

\footnotetext{
${ }^{6}$ Note that the latter holds because $\partial^{2} c(e, t, \tau,) / \partial e \partial t=0$.
} 
The first order-condition with respect to $t$

$$
B(t, \tau,)= \begin{cases}-h(1-\tau)(\partial w / \partial t)+(\partial T / \partial t), & \text { if } 0 \leq \leq \\ (1-t)(\partial w / \partial t)-w+(\partial T / \partial t), & \text { if }<\leq 1\end{cases}
$$

where

$$
\frac{\partial T}{\partial t}=(1-) w+[t(1-)-\tau h] \frac{\partial w}{\partial t}+(\tau \pi-t w) \frac{\partial}{\partial t}
$$

implicitly defines the tax rate $t$ as a function of $\tau$, , or $t(\tau, ; e)$, for $e \in\{M, W\}$. The secondorder condition for a maximum is $B_{t}<0$.

We can now examine how $t$ changes with . By the implicit function theorem,

$$
\frac{\partial t}{\partial}=-\frac{B}{B_{t}}
$$

From the second order condition, $B_{t}<0$. This means that the sign of $\partial t / \partial$ is determined by the sign of $B$. In what follows, we consider a numerical example to study the sign of (3.15).

\section{Numerical example}

In order to obtain further results, we construct a numerical example. We assume that $F(H)=H^{\alpha}$. In this case, the demand for labor for each firm or manager is $H=(\alpha / w)^{1 / 1-\alpha}$. We use the following parameter values: $\alpha=0.80, \gamma=0.20$, and $=0.20$.

Tables 3.1 and 3.2 show the results of the numerical example. Each table presents the values of the endogenous variables for different levels of outsourcing, represented by . The results reported in Table 3.1 correspond to the workers' preferred labor tax rate, and Table 3.2 shows the labor tax rate rate chosen by managers. It is clear from both tables that as the amount of outsourced labor rises, the tax rate decided by majority voting unambiguously goes down when both $\in M$ and $\in W$. The difference between $t^{w}$ and $t^{m}$ is given precisely by their levels, i.e., $t^{w}<t^{m}$ for all . 
At higher values of, profits go up, so the relative supply of managers increases as well. Hence, the equilibrium level of $w$ becomes higher. Since profits go up, workers can choose a lower labor tax rate, which raises their net wage $w(1-t)$, while still observing an increase in total taxes $T$. The latter occurs because the higher level of profit taxes more than compensates the decline in $t^{w} w(1-)$. For managers, the preferred labor tax is considerably higher. Even though net profits are smaller in this case relative to the case where workers determine the tax rate, total taxes substantially increase, making managers better off. As a result, managers are able in this way to increase their disposable income by redistributing income from workers.

The paper by Razin et al. (2002) focuses on the impact of immigration. In a similar setup, they show that immigration may have an ambiguous effect on domestic income tax rates. They claim that, in fact, it is likely to expect lower tax rates and, hence, a lower amount of redistribution, in the presence of low-skill immigration. The idea is that low-skill immigrants may end up receiving a disproportionate amount of the transfers targeted to low income groups. Thus, low-skill natives may find it desirable to vote for lower income taxes along with high-skill individuals. As they state in their paper, this result contrasts with the "conventional wisdom"; it is generally claimed that the presence of low-skill immigrants leads to a increase in the domestic tax burden because both the low-skill natives and low-skill immigrants join forces to vote for higher levels of taxes and redistribution. Our results, on the other hand, show that outsourcing unambiguously decreases the political equilibrium labor tax rate, indicating that once redistributive effects are taken into account through the political process, immigration and outsourcing may end up affecting the domestic economy in completely different ways. 


\subsection{Profit tax rate}

We now obtain the profit tax rate reached under majority voting. Throughout the analysis we keep the labor tax rate constant. Deriving (3.11) with respect to $\tau$, we obtain

$$
D(t, \tau,)= \begin{cases}-h(1-\tau)(\partial w / \partial \tau)-\pi+(\partial T / \partial t), & \text { if } 0 \leq \leq \\ (1-t)(\partial w / \partial \tau)+(\partial T / \partial t), & \text { if }<\leq 1\end{cases}
$$

where

$$
\frac{\partial T}{\partial \tau}=\pi+[t(1-)-\tau h] \frac{\partial w}{\partial \tau}+(\tau \pi-t w) \frac{\partial}{\partial \tau} .
$$

Expression (3.16) implicitly defines $\tau(t, ; e)$ for $e \in\{M, W\}$. The second-order condition for a maximum is $D_{\tau}<0$.

Our objective, as before, is to determine the impact of higher levels of outsourcing on $\tau$, i.e., $\partial \tau / \partial$, for a given labor tax rate.

\section{Numerical example}

Table 3.3 shows the workers' preferred profit tax rates for different values of , and Table 3.4 shows the corresponding values for managers. Throughout the exercise, the labor tax rate $t$ is kept constant at 0.15 . The results are exactly the opposite as those obtained earlier, for the case of labor tax rates. The political equilibrium profit tax rate increases as the amount of outsourced labor rises for both $\hat{e} \in W$ and $\hat{e} \in W$. However, $\tau^{w}>\tau^{m}$ for all .

A higher level of increases the supply of managers and decreases the supply of workers. Managers voting on the level of $\tau$ take this effect into account by choosing a higher level of $\tau$, partially compensating for the process generated by the higher level of . The net outcome is, however, a higher values of and $w$, but these are lower than they would have been otherwise. 


\section{Conclusion}

The present study focuses on the effect of outsourcing on labor and profit tax rates. The main findings are that an increase in international outsourcing of low skill jobs leads to lower labor taxes and higher profit taxes. If we combine these results with those of Eeckhout and Jovanovic (2007), the implication of this study is that we should observe low labor taxes and high profit taxes in the developed countries that have over time been increasingly sending low skill jobs abroad to make use of cheap labor. Contrarily, the low income labor intensive countries providing distant low skill services to the outsourcing firms should exhibit high labor taxes and low profit taxes.

A future version of this model would drop the assumption of firms having identical demand for labor expost. Firms would differ in their labor demand based on productivity differences. While we expect the basic outcomes to remain unaffected, the latter version does make way for a more realistic representation of the problem under consideration.

The model could be further extended to include low skill immigration and examine its effects on these tax rates. Our hypothesis is that an increase in low skill immigration should increase labor tax rates since now there would be a "leakage" in transfers since a part of it is claimed by the immigrants. If that is true then the model should also be able to show that contrary to popular belief immigration and outsourcing may not always act as substitutes. 
Table 3.1: Optimal labor tax rate for workers: different levels of outsourcing

\begin{tabular}{c|ccc|cc|ccc}
\hline & $t^{w}$ & $w$ & $H$ & $N$ & $t^{w} w(1-)$ & $\tau \pi$ & $T$ \\
\hline 0.90 & 0.0981 & 0.3967 & 0.6703 & 2.4209 & 0.6839 & 0.0397 & 0.0575 & 0.0972 \\
0.95 & 0.0939 & 0.4216 & 0.6759 & 2.3222 & 0.6968 & 0.0367 & 0.0623 & 0.0990 \\
1.00 & 0.0894 & 0.4489 & 0.6816 & 2.2275 & 0.7105 & 0.0336 & 0.0677 & 0.1012 \\
1.05 & 0.0844 & 0.4790 & 0.6872 & 2.1375 & 0.7251 & 0.0302 & 0.0737 & 0.1039 \\
\hline \multicolumn{6}{c}{ Parameter values: } \\
\hline
\end{tabular}

Table 3.2: Optimal labor tax rate for managers: different levels of outsourcing

\begin{tabular}{c|ccc|cc|ccc}
\hline & $t^{m}$ & $w$ & $H$ & $N$ & $t^{m} w(1-)$ & $\tau \pi$ & $T$ \\
\hline 0.90 & 0.2957 & 0.5920 & 0.7292 & 1.5892 & 0.6320 & 0.0880 & 0.0794 & 0.1673 \\
0.95 & 0.2873 & 0.6344 & 0.7351 & 1.5263 & 0.6508 & 0.0772 & 0.0876 & 0.1648 \\
1.00 & 0.2783 & 0.6804 & 0.7407 & 1.4697 & 0.6706 & 0.0659 & 0.0968 & 0.1627 \\
1.05 & 0.2690 & 0.7301 & 0.7458 & 1.4198 & 0.6912 & 0.0542 & 0.1070 & 0.1612 \\
\hline \multicolumn{8}{c}{ Parameter values: } \\
\hline
\end{tabular}


Table 3.3: Optimal profit tax rate for workers: different levels of outsourcing

\begin{tabular}{c|ccc|cc|ccc}
\hline & $\tau^{w}$ & $w$ & $H$ & $N$ & $t w(1-)$ & $\tau^{w} \pi$ & $T$ \\
\hline 0.90 & 0.2170 & 0.3967 & 0.6703 & 2.4209 & 0.6491 & 0.0607 & 0.0714 & 0.1320 \\
0.95 & 0.2199 & 0.4216 & 0.6759 & 2.3222 & 0.6589 & 0.0586 & 0.0783 & 0.1369 \\
1.00 & 0.2230 & 0.4489 & 0.6816 & 2.2275 & 0.6691 & 0.0563 & 0.0862 & 0.1425 \\
1.05 & 0.2263 & 0.4790 & 0.6872 & 2.1375 & 0.6800 & 0.0537 & 0.0953 & 0.1490 \\
\hline \multicolumn{6}{c}{ Parameter values: } \\
\hline
\end{tabular}

Table 3.4: Optimal profit tax rate for managers: different levels of outsourcing

\begin{tabular}{c|ccc|cc|ccc}
\hline & $\tau^{m}$ & & $w$ & $H$ & $N$ & $t w(1-)$ & $\tau^{m} \pi$ & $T$ \\
\hline 0.90 & 0.0363 & 0.5920 & 0.7292 & 1.5892 & 0.7382 & 0.0446 & 0.0164 & 0.0611 \\
0.95 & 0.0471 & 0.6344 & 0.7351 & 1.5263 & 0.7517 & 0.0403 & 0.0236 & 0.0639 \\
1.00 & 0.0580 & 0.6804 & 0.7407 & 1.4697 & 0.7657 & 0.0355 & 0.0321 & 0.0676 \\
1.05 & 0.0691 & 0.7301 & 0.7458 & 1.4198 & 0.7800 & 0.0302 & 0.0423 & 0.0725 \\
\hline
\end{tabular}

Parameter values:

$\alpha=0.80, \gamma=0.20,=0.20, t=0.15$. 


\section{Chapter 4}

\section{Immigration, Outsourcing and Tax}

\section{Policy: Evidence from OECD}

\section{Countries}

\section{Introduction}

"Outsourcing and immigration remain an economic mirror image of each other", a recent article on Forbes said $1^{1}$ As the global boundaries started to loosen over more than a decade now, factor mobility also got redefined. This is especially true for economically developed countries. Not only these countries attract cheap labor from the developing world, but they also send out part or whole of their own jobs to the labor abundant low income countries. Soon enough the cost saving strategies began to boomerang and strong feelings of insecurity spread among the domestic labor force of the advanced part of the world. These two highly controversial and influential products of globalization, namely immigration and outsourcing, are much talked about in both economic and political spheres of the first world. The goal of this paper is precisely to examine from a political economy point of view the effects

\footnotetext{
${ }^{1}$ The article written by Robert Malone appeared in Forbes.com, May 2007 <http: //www.forbes.com/2007/05/21/outsourcing-world-atlas-biz-cx_rm_0522atlas.html>
} 
of international migration and outsourcing on public finance concerns by focusing on the resulting impact of these two alternatives on domestic labor taxes.

When a country's market opens up to cheap foreign labor force, either by immigration or by outsourcing, the domestic labor market is bound to get affected. Is their a difference as far as their impact on the domestic labor market is concerned? We claim that different levels of immigration and outsourcing affect domestic economic agents in conflicting ways. Hence, under majority voting, we expect different equilibrium levels of domestic labor tax rates chosen in each case.

The present study is built upon the integration of different issues; at least two of them have been studied fairly widely $!^{2}$. The first one concerns the relationship between domestic government expenditures (or domestic taxation) and inflows of immigrants. A few papers in this area have tried to identify the effect of immigration on domestic tax burden by distinguishing immigrants of different skill levels. Most of this work concludes that lowskilled immigrants would tend to increase fiscal burden, while high-skill immigrants would have the opposite effect (see, for instance, Camarota (1998); Razin et al. (2002); Coleman and Rowthorn (2004); and Borjas (1994)). Our work can be viewed as a contribution to this literature. In particular, we are interested in determining how immigration affects the choice of domestic tax rates when decisions are made following a political process.

The second issue refers to the connection between both immigration and outsourcing and labor productivity. Some literature claims that immigration raises the productivity of native workers; differences in workers' types establish a complementary relationship between domestic labor and immigrant labor ${ }^{3}$ International outsourcing, through a different channel, may also raise the real wage rate of domestic labor if the country outsources labor intensive jobs and specializes itself in capital or skilled labor intensive production $4^{4}$ For our paper,

\footnotetext{
${ }^{2}$ We will review this literature more carefully in 2

${ }^{3}$ See, for instance, Jones (2005). Along the same line of reasoning, Peri and Sparber (2006) suggest that task specialization among low skilled immigrants and low skilled natives within the domestic economy may help mitigate the negative impact of increased low skilled migration on domestic wages.

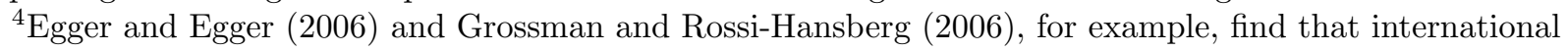
outsourcing increases productivity of low skilled labor in the long run.
} 
these effects will be relevant to the extent that they affect voters' choice of their preferred domestic labor tax rate.

An additional issue, which has not received much attention in the literature to our knowledge, concerns the differential impact of outsourcing and immigration on government expenditures. As mentioned earlier, it is generally assumed that low-skill immigrants would tend to receive an important proportion of government transfers resulting in an increase in tax burden. Outsourcing, however, would not have such an impact. As a consequence, a lower tax burden should be expected in economies that rely more heavily on outsourcing.

Our approach differs from the current literature on outsourcing and immigration in at least two ways. First, we focus on both immigration and outsourcing at the same time. Second, we consider the political determinants of domestic labor tax rates for different levels of outsourcing and immigration. We adopt a similar line of reasoning as the one followed by , but extending the analysis to include outsourcing as well.

The empirical analysis is based on the study of 15 OECD countries from 1990 to 2001, typically referred to as the globalization period. The results show that immigration and outsourcing may have quite contradictory effects on domestic labor tax rates, contrary to popular belief that they are simply "mirror images".

The rest of the paper is organized as follows. Section 2 provides a review of recent literature on the topics of immigration, outsourcing, and tax policy; section 3 describes the data and the empirical approach; and section 4 presents the results of our analysis.

\section{Conceptual Framework and Related Literature}

In this section we provide an account of related literature that serves to develop our conceptual framework of analysis and to establish the grounds of the empirical analysis performed in Section 3. Our claim is that outsourcing and immigration do not necessarily have the same distributional effect on domestic agents. Thus, from a political economy point of view this 
differential impact would entail different voting outcomes and different tax/transfer policies. For instance, low-skilled immigration is generally associated with higher taxes and more government redistribution. Outsourcing, on the other hand, may even signify lower welfare transfers. To the extent that these results hold, voting outcomes would be different in these two cases. Additionally, part of the distributional impact takes place through the domestic labor market; low- and high- skilled workers may be affected differently by outsourcing and immigration. Our study focuses specifically on labor income tax rates and considers the following question: assuming that tax rates are chosen by majority voting, does different levels of outsourcing and immigration entail different voting outcomes?

As pointed out earlier, the present study can be viewed as an integration of three separate issues. The first one concerns the impact of immigration on domestic public finance. The second issue refers to the relationship between outsourcing and immigration and labor productivity. The third aspect of our work, the connection between outsourcing and labor tax rates does not have, to our knowledge, any predecessor. We address next each of these areas separately.

\subsection{Immigration and Tax Policy}

Fiscal effects of immigration have been examined vividly and conclusions from these studies lack uniformity. The literature on this subject is vast; we name a few. Most of the research in this field concludes that immigration of low skilled workers increases fiscal burden, since low skilled immigrants are poor in general and, therefore, the benefits they receive from the welfare state exceed their tax obligations. The consequence of immigration is, according to this literature, an increase in tax burden on domestic labor. Dolmas and Huffman (2004) provide a political economy analysis of immigration, government spending and taxation. Their model predicts that a higher inequality in the distribution of capital will turn the

median voter against policies favoring immigration. In such a situation immigration will induce the median voter to vote for higher tax rates; since high inequality is likely to place 
the median voter in the low income group.

However, Razin et al. (2002) show that this may not be necessarily true. They set up a political-economy model that accounts for "two conflicting effects" of international migration on tax and redistributive policies. Low skilled or low income immigrants join the low income natives to vote for higher taxes and transfers. At the same time, "fiscal leakages" (i.e., transfers going to low skilled immigrants) induce low skilled natives to join the anti-tax coalition and vote for lower taxes. If the latter effect dominates, the net impact of unskilled immigration on domestic labor tax is negative. That is, low skilled immigration lowers tax rates on domestic labor. Their theory also predicts that medium and high skilled immigration, on the contrary, has a positive impact on labor tax rate. Razin et al. (2002) provide support to their theory with empirical evidence from 11 European countries. They find that, after controlling for factors that play important roles in determining the size of the welfare state, low skilled immigration lowers tax burden on domestic labor and high and medium skilled immigration increases it. In our empirical model, we consider a variant of Razin et al. (2002) focusing simultaneously on both outsourcing and immigration.

Borjas (2006) shows that income distribution moved largely in favor of the employers as a result of immigration. He argues that immigration has little impact on fiscal issues like payroll taxes, and that an increase in low-skill migration may actually raise these taxes to some extent. He also acknowledges the fact that the skill composition of immigrants does matter in the determination of income distribution. Low skilled immigration may reduce the wages of the competing low skilled natives, but raise the wages of complementary high skilled domestic workers. Influx of high skilled immigrants will have the opposite effect. Coleman and Rowthorn (2004) analyze the economic effects of immigrants in the United Kingdom. They argue that immigrant population can lower the tax burden on natives by sharing a part of that burden. Camarota (1998) interprets the findings of the National Research Council (NRC) regarding immigration trends in the United States and its implications for the fiscal burden at various levels of the federal structure. He argues that at the state and local levels 
immigrants impose a considerable amount of extra tax burden, in other words, they receive more public benefits relative to their tax contributions. At the federal level, on the other hand, immigrants pay more taxes than value of transfers they receive. The net impact is, however, an increase in fiscal burden. This paper also points out that the fiscal impact of immigrants largely depends on their skill levels $5^{5}$ Low skilled immigrants earn less income, pay less taxes, and enjoy more transfers; the opposite is true for high skilled immigrants.

The empirical strategy that we follow in Section 3 aims at determining whether immigration and outsourcing behave as "substitutes" in the context of public finance. We examine the extent to which different levels of immigration and outsourcing are in effect neutral in terms of their impact on domestic tax policies. However, in light of the conclusions of the work discussed above, it is necessary to account for the skill composition of immigrants in order to approach this question correctly.

\subsection{Immigration, Outsourcing, and Labor Productivity}

The few studies that compare the effect of immigration and outsourcing on domestic labor productivity reveal to some extent certain degree of substitutability between the two alternatives in various respects. Jones (2005), for example, studies the impact of immigration and international outsourcing on the domestic labor market. He argues that both immigration of unskilled workers and outsourcing of labor intensive production processes may raise the marginal productivity of local workers. Yomogida and Zhao (2005) examine the connection between immigration and outsourcing with respect to their effects on labor markets for skilled and unskilled workers and wage inequality. They conclude that unskilled immigration and fragmentation of production processes have similar impact on the labor market, and skilled immigration and outsourcing of services behave, under certain conditions, in the same way. Bandyopadhyay and Wall (2006) present a general equilibrium model with immigration and

\footnotetext{
${ }^{5}$ In the 1950s and 1960s a few European countries implemented immigration policies which granted temporary work permits to immigrants. However, these policies did not have the expected effect. In reference to the failure of these policies, the Swiss writer Max Frisch has been claimed to say: "We asked for workers. We got human beings"
} 
outsourcing and show that if immigration quotas are relaxed, outsourcing declines, implying that they would act as substitutes.

In this paper, however, we claim that in terms of their impact on domestic public finance immigration of low skilled workers and outsourcing may, in fact, end up having completely opposite effects, somewhat against conventional belief.

\subsection{Outsourcing and Tax Policy}

The controversy on outsourcing is mostly restricted to the possible impact of this phenomenon on domestic labor markets. At large, the economic and political debate is focussed on whether the outsourcing of jobs to low wage economies is endangering the job prospects of domestic workers. There is no study until now, that we are aware of, examining the fiscal effects of outsourcing. Some research do look at the impact of trade on tax policies.

For instance, Rodrik (1997) shows that trade increases tax burden on domestic labor. Hanson et al. (2005) consider the role of immigration and trade in shaping people's opinions about globalization strategies. They claim that while immigration causes a "fiscal leakage" in transfers, the problem does not exist when a country imports the goods that would have been otherwise produced by the immigrants. They conclude that natives are likely to oppose immigration if it increases fiscal burden, but public finance concerns do not affect the natives' preference for a freer trade policy.

In our paper, we use Hanson et al. (2005)'s argument to justify why outsourcing should have any fiscal impact whatsoever. Like trade, outsourcing poses no claim on domestic transfers. Therefore, choosing outsourcing over immigration may reduce the tax burden on domestic labor. 


\section{Empirical Analysis}

In order to test whether immigration and outsourcing have differential impacts on domestic taxes, we construct a regression model which extends Razin et al. (2002) by including different measures of outsourcing. Specifically, the empirical strategy consists on regressing domestic labor income tax rates on immigration, outsourcing, and other control variables. We examine 15 OECD countries from 1990-2001. The choice of countries is mainly guided by the fact that these countries have been the immigration hub and, at the same time, are becoming increasingly dependent on international outsourcing $5^{6}$ We also lag the explanatory variables by one period in our analysis. This accounts for the lags with which fiscal policies operate and also takes care of contemporaneous correlation issues.

The dependent variable in our regression model is effective labor tax rate which is measured following Mendoza et al. (1994). Figure 1 shows the behavior of this variable along time and across countries.

Immigration is measured either as the share of foreign born or foreign population in total population, depending on what the countries report. 7 Figure 2 shows the trend of international migration as a share of total population. In general, this share has been increasing over time, but the behavior across countries is not uniform. The United States is, as expected, the highest recipient of international immigrants. We also adopt Razin et al. (2002)'s methodology in constructing the data on immigrants on the basis of their educational attainment, since data exists only for 1995.8

Absence of a unique indicator of outsourcing has resulted in the use of multiple measures

\footnotetext{
${ }^{6}$ We show later different indicators that confirm this last claim.

${ }^{7}$ Illegal immigration is also an issue in the present context. An increase in the number of illegal migrants may affect domestic labor tax burden. However, we do not consider this case in our empirical study.

${ }^{8}$ Following Razin et al. (2002), the assumption that educational composition of migrants remain constant over the time period under consideration, generates the following measure:

$$
\left(\frac{\text { High education immigrants }}{\text { Population }}\right)_{1990-2001}=\left(\frac{\text { Immigrants }}{\text { Population }}\right)_{1990-2001} \times\left(\frac{\text { High education immigrants }}{\text { Population }}\right)_{1995} .
$$
}

We use similar techniques to get data on low and medium education immigrants. 
in the existing literature; our model uses three of such measures. The first one, Outsourcing, is defined following Egger and Egger (2006) as the share of imported intermediate inputs in the same 2 digit industry as in total output. The second measure, Outsourcing $g_{2}$ has been constructed following Feenstra and Hanson (1999); it is the share of imported intermediate inputs in total non-energy intermediates. Finally, Outsourcing 3 a third indicator, also used by Grossman and Rossi-Hansberg (2006), measures the share of imported intermediates in total output 9 Figure 3 shows the trends in international outsourcing for the OECD countries in our sample. All indicators increase for every country during the period under analysis confirming an intense process of globalization.

We also control for other factors that possibly affect government expenditures and public policies, and hence the effective labor tax rate. Below we provide a description of each of these variables.

Income distribution and income inequality, in theory, are supposed to be crucial determinants of government redistribution policies. They account for the fact that the median voter plays a pivotal role in determining redistribution policies, so we should be looking at the share of income accruing to the middle income group 10 Two standard indicators have been used in the analysis. The first one is the rich/middle measure constructed by dividing the uppermost decile by the middle. The second measure is the poor/middle measure constructed by dividing the middle decile by the lowest 11

Other controls in the model include share of government employment in total employment, and dependency ratio, calculated by subtracting the share of labor force in total population from one. The size of the government sector is likely to increase government expenditures and make a case for higher taxes. The issue of dependency ratio and its fiscal impact has been studied fairly widely, the conventional idea being that an increase in this variable exerts additional fiscal pressure. Trade openness given by the share of imports and

\footnotetext{
${ }^{9}$ Please, see Appendix $\mathrm{B}$ for a detailed explanation about the construction of each measure. ${ }^{10}$ See Razin et al. (2002).

${ }^{11}$ The results are robust to the use of alternative income inequality measures, such as the Gini coefficient.
} 
exports in real GDP captures the effect of external shocks. Short run income fluctuations are accounted for by including the annual growth rate of real GDP per capita. Finally, since increase in unemployment rate puts toll on government transfers, it is also included as a control in the model 12

Table 1 presents a summary of the data and correlations between the explanatory variables and the dependent variable, labor tax rate. The coefficients for immigration and all three measures of outsourcing are of opposite signs. The correlation coefficients reveal the conflicting effects of immigration and outsourcing on labor tax rate mentioned earlier. Also, as shown in Table 2 all three measures of outsourcing are highly positively correlated, so that they can be used as alternate indicators of the same phenomenon 13

\section{Results}

We estimate our model considering a pooled regression with country fixed effects, following closely the strategy adopted by Razin et al. (2002). Table 3 shows the regression results. The "baseline specification" includes one period lags of share of government employment in total employment, dependency ratio, per capita GDP growth, trade openness, and two indicators of income inequality.

Column (1) in Table 3 presents the outcome of the first regression, which does not include immigration or outsourcing. The share of government employment is positively correlated with labor tax rate, however, it is not statistically significant. Thus, even though an increase in the government participation in the labor market is likely to increase tax burden, the impact does not seem to be particulary strong. Dependency ratio has a negative coefficient,

\footnotetext{
${ }^{12}$ We are aware of the reverse type of causality under which higher taxes would imply higher levels of unemployment. Daveri and Tabellini (2000), for instance, claim that if the labor market is not competitive and workers have monopolistic power, the burden of labor tax is shifted to firms and that increases unemployment. OLS regressions with unemployment rate as the dependent variable and share of migrants in total population and outsourcing as the independent variables show that while migration has a positive correlation with unemployment rate, it is not statistically significant. All outsourcing measures have negative correlations with unemployment rate and outsourcing 1 and 2 are statistically significant. We include unemployment in our analysis to make it comparable to the results of Razin et al. (2002).

${ }^{13}$ See Appendix C for a description of the data sources.
} 
supporting Razin et al. (2002)'s hypothesis that a growing aging population germinates antitax feelings among the working population and they vote for lower taxes. However it is not statistically significant. level. Trade openness has a highly significant positive effect on labor tax rate, consistent with the Rodrik (1997). Per capita GDP growth has a negative and insignificant coefficient. The two income inequality indicators have somewhat conflicting effects. Rich/Middle has a very significant negative coefficient, quite opposite to what we would expect. A higher income inequality may put more people in lower tax brackets, thus bringing down the burden of tax rate on labor. The second indicator poor/middle income share is not significant at all.

Column (2) adds lag of share of immigrants in population to the model. The result shows that international migration raises the labor tax rate, supporting popular belief. The coefficient, however, is significant only at 16 percent level. An increase in the flow of international immigrants puts additional pressure on government transfers increasing the labor tax rate. This is not unlikely, as claimed by Borjas (1994); 10 percent of households receiving public assistance in 1990 and 13 percent of total cash assistance recipients consisted of foreign-born households in the United States. Camarota (1998) also points out that a National Research Council (NRC) study reveals that the value of public assistance accruing to immigrant households exceed their tax payments. Hence, there is a net increase on fiscal burden. The result obtained in our empirical analysis, that immigration increases the tax burden on domestic labor, may partly be explained by that finding 14

The next step of the analysis accounts for educational composition of immigrants. Existing literature acknowledges the fact that the impact of immigration on domestic labor market as well as the burden imposed on the welfare state is to some extent shaped by the skill composition of immigrants. Therefore, we decompose the total share of immigrants into high, medium and low education as defined in the OECD database ${ }^{15}$ In the regression,

\footnotetext{
${ }^{14}$ Note that the inclusion of the immigration variable does not alter the estimates of the other controls.

${ }^{15}$ The OECD database defines low education immigrants as those who have less than first stage of second level schooling. Medium education immigrants include those who have completed second stage of second level and immigrants who have completed third level belong to the high education category. High skilled
} 
however, we simply include total immigrant share and high and medium education migrants share clubbed together ${ }^{16}$ Column (3) shows individual effects of high and low skilled migration. Classifying immigrants on the basis of their skill levels, in fact, makes immigration an important determinant of labor tax rate. High and medium skilled migrants have a negative correlation with labor income tax rate, whereas a higher share of low skilled immigrants (now captured in the variable "Migrants/Population") increases tax burden on domestic labor. ${ }^{17}$ In terms of magnitude, low skilled immigration has a less impact than high skilled, although the former is statistically more significant than the latter. This is also consistent with existing literature, though it fails to establish Razin et al. (2002) hypothesis that an increase in low skilled immigration lowers domestic tax burden by inducing the low skilled workforce to join the anti-tax coalition. It is interesting to observe that not only the direction of the effect of low and high skilled immigrants is different, but they also differ in their magnitudes. The estimates indicate that the increase in labor tax burden caused by low skilled immigrants is largely more than compensated by the impact of high skilled immigrants. The disparity with the Razin et al. (2002) model with respect to the effect of immigration on labor tax burden can be attributed to the difference in time periods and selection of countries in the two models. For instance, our dataset includes the United States, the highest recipient of immigrants. Hence the negative impact of immigrants on the welfare state resulting in higher taxes seems plausible. Other controls remain more or less unaltered.

Lagged unemployment rate is then added to the model; the estimated coefficients are shown in column (4). The signs on the low skilled and high skilled migration variables remain unchanged, however, now high skilled immigration has no significant impact of labor

\footnotetext{
immigrants in this model is the sum of high and medium education immigrants in total population.

${ }^{16}$ The reason we do not include both low skilled and high skilled measures together is due to the fact that the OECD dataset on "Population and labor force by level of education", also consists of a category whose country of origin (national or foreign) is unknown and so is the level of education. Therefore taking into account simply the measures of immigration by education level may yield misleading results. Razin et al. (2002) also adopt the same strategy.

${ }^{1 \bar{T}}$ This reflects Camarota's (1998) argument that unlike low skilled migrants, high skilled immigrants earn higher income and therefor pay higher taxes. However the high skilled migrants receive smaller transfers and thus an increase in high skilled immigrants may lower tax burden on domestic labor.
} 
taxes, while low skilled is significant only at the 25 percent level.

At this stage we introduce "outsourcing" in the empirical model. Three alternative measures of outsourcing are used individually on the base model (excluding migration and unemployment rate). It is worth noting that all outsourcing indicators essentially reflect low skilled jobs, since they include only manufacturing industries. Columns (5), (6) and (7), respectively, show the effects of different indicators of outsourcing (Outsourcing ${ }_{1}$, Outsourcing ${ }_{2}$, and Outsourcing $_{3}$ ) on labor tax rates. All measures seem to have a negative and significant impact on the dependent variable. The coefficients show that for the first measure, a unit increase in outsourcing will lower tax burden by 0.03 . The second measure has a comparatively smaller impact, while the effect of outsourcing captured by the third indicator seems

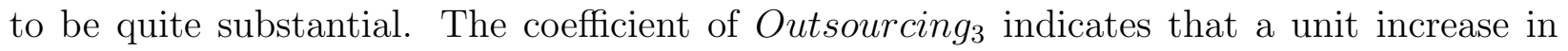
outsourcing lowers tax rate by approximately 0.69 units. These results are consistent with the hypotheses that outsourcing, especially of low skill activities, enhances productivity of domestic labor force. Work in this area finds that in the long-run, an increase in international outsourcing increases the productivity of low skilled workers for the US manufacturing industries (see Feenstra and Hanson (1999)) and in EU manufacturing industries (see Egger and Egger (2006)). Grossman and Rossi-Hansberg (2006) also show that international off-shoring is equivalent to technological advancement and as a result enhances the productivity of the factor whose job is being outsourced. Our results may be reflecting this fact. If domestic low skilled workforce becomes more productive and income distribution moves in favor of them, they move up the tax bracket and are likely to join the high-skilled in the anti-tax coalition. Therefore international outsourcing of low skilled jobs should lower domestic tax burden. The results remain unaltered with the addition of unemployment. In fact Outsourcing Ond $_{1}$ Outsourcing 2 become even more significant. These results are not reported.

Finally, the model includes low and high skilled immigrants and outsourcing. Column (8) reveals that, contrary to popular belief, low skilled immigration and outsourcing have 
opposite effects on labor tax rate. Low skilled immigration increases tax burden on domestic labor, while low skilled outsourcing lowers the burden ${ }^{18}$ Also both immigration and outsourcing are significant. In terms of the magnitude of their impacts, low skilled immigration has a more important effect than outsourcing. This is expected since the fiscal impact of foreign labor force located outside the country is more subtle. Column (8) also shows that the estimated coefficients of high skilled immigration and outsourcing are essentially the same as the estimates obtained when each variable is introduced at a time. No significant changes are observed in the estimated coefficients of other control variables.

The subsequent columns (9) and (10) use alternative measures of outsourcing. Again most of the basic results remain unchanged. Low skilled migration and Outsourcing are $^{2}$ significant at the 5 percent and high skilled migration is significant at the 10 percent level. Outsourcing $_{3}$ also has a negative coefficient, and significant only at the 5 percent level. High skilled migration, however, is now significant at the 12 percent level, while low skilled migration continues to be significant at the 5 percent level. All these cases reveal that low skilled outsourcing and low skilled immigration have significantly opposite impact on effective labor tax rate.

Columns (11),(12) and (13) reestimates the model using skill compositions of immigrants and alternative measures of outsourcing in the presence of unemployment rate. Outsourcing ${ }_{1}$ and Outsourcing $_{2}$ become even more significant, while Outsourcing 3 is now significant at the 10 percent level. High skilled migration still bears a negative relationship with labor tax rate, however, it is not statistically significant anymore. Low skilled migration also maintains its positive sign although it is now significant at about 27 percent level on average. The results support our claim that low skilled immigration and outsourcing have very different implications regarding labor tax rates.

To summarize, our empirical results show that low skilled immigration and outsourcing

\footnotetext{
${ }^{18}$ Regressions including only the share of immigrants and not considering educational classification, also show that immigration has a positive, while outsourcing has a negative impact on labor tax rate. Only migration share is significant at the 20 percent level on average. We do not report these results.
} 
of low-skilled related activities, tend to have opposite effects on the domestic labor tax rate. An increase in the number of low skilled migrants increases the tax rate, while an increase in outsourcing of low skilled jobs lowers it. Thus, our results support the idea that immigration of low-skilled workers would tend to increase the fiscal burden. Outsourcing of low skilled jobs, however, may result on lower domestic tax rates since outsourcing does not make any claims on government transfers. 19 Furthermore, our findings are consistent with the research that shows that outsourcing enhances productivity of low skilled labor. The idea is that as wages of low-skilled go up with outsourcing, they may choose to join the anti-tax coalition with the high-income group.

\section{Conclusion}

International migration and outsourcing are currently issues of major policy concerns. Existing research rarely brings these two alternatives together, mostly due to the general idea that they are both sides of the same coin. Few studies look jointly at immigration and outsourcing from a theory of production and labor market perspective. The common element of these theories is the treatment of immigration and outsourcing as "substitutes".

Our results show that the fact that immigration and outsourcing are "mirror images" cannot be generalized; if we look at the two from a public finance viewpoint we find that they both significantly affect domestic tax burden but in very different and rather opposite ways; while low-skilled immigration raises the domestic labor income tax rate, outsourcing tends to reduce it.

The findings of this study further reinforce some earlier work on the effect of outsourcing on domestic workers. It has been claimed in earlier literature that outsourcing increases productivity (and, hence, real wages) of domestic low-skilled workers. From a political

\footnotetext{
${ }^{19}$ We also construct a measure of per capita transfers using OECD National Accounts data on social expenditures. We then estimate OLS regressions with per capita transfers as the dependent variable and migration share and outsourcing as independent variables. Neither immigration or outsourcing have significant impact on welfare expenditures. In particular, immigration has a negative coefficient while outsourcing is found to have an ambiguous relation with per capita transfers depending on which outsourcing indiactor we use.
} 
economy perspective, it can be argued that this group of workers will then have incentives to join the high-income group and vote for lower domestic labor tax rates. Along this same line of reasoning, and light of our results, low skilled immigration should not have the same impact as foreign outsourcing on labor productivity. 
Figure 4.1: Effective labor tax rate in 15 OECD countries, 1990-2001

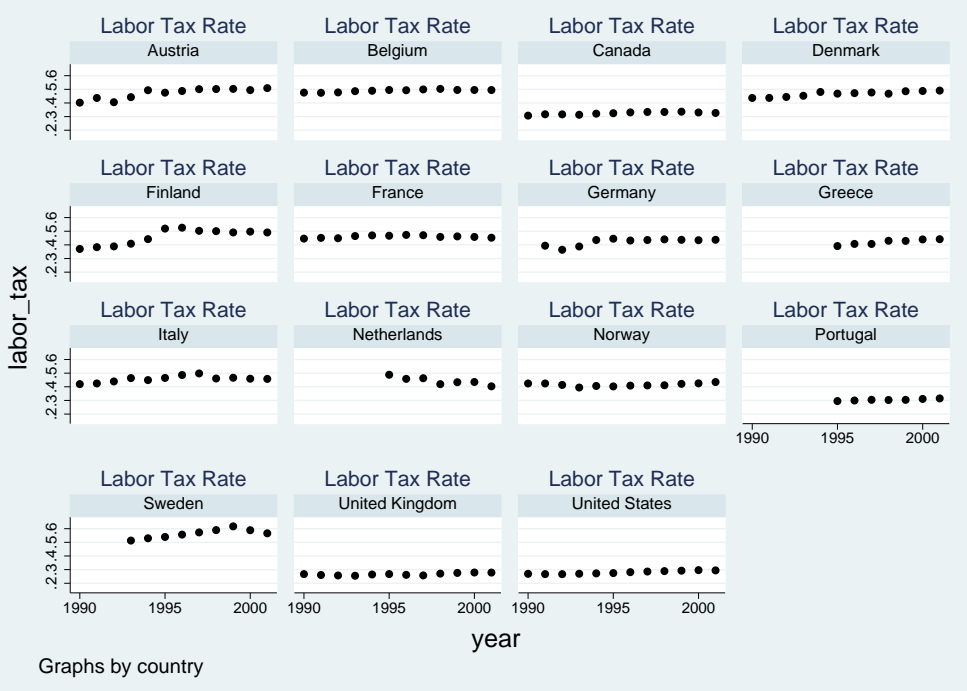

Figure 4.2: Share of migration in total population in 15 OECD countries, 1990-2001

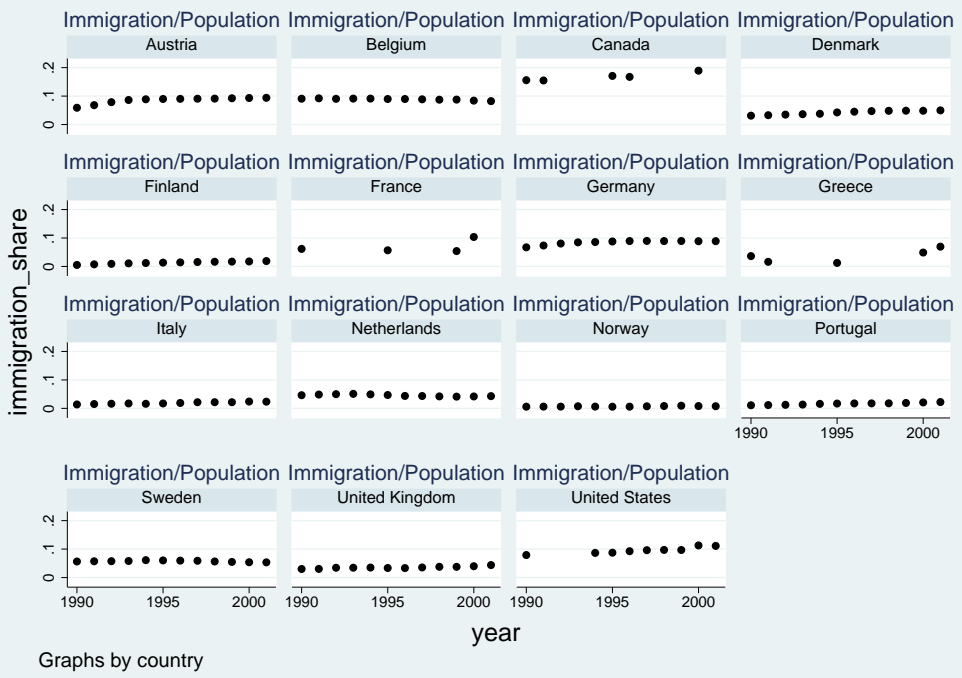


Figure 4.3: Outsourcing in 15 OECD countries, 1990-2001

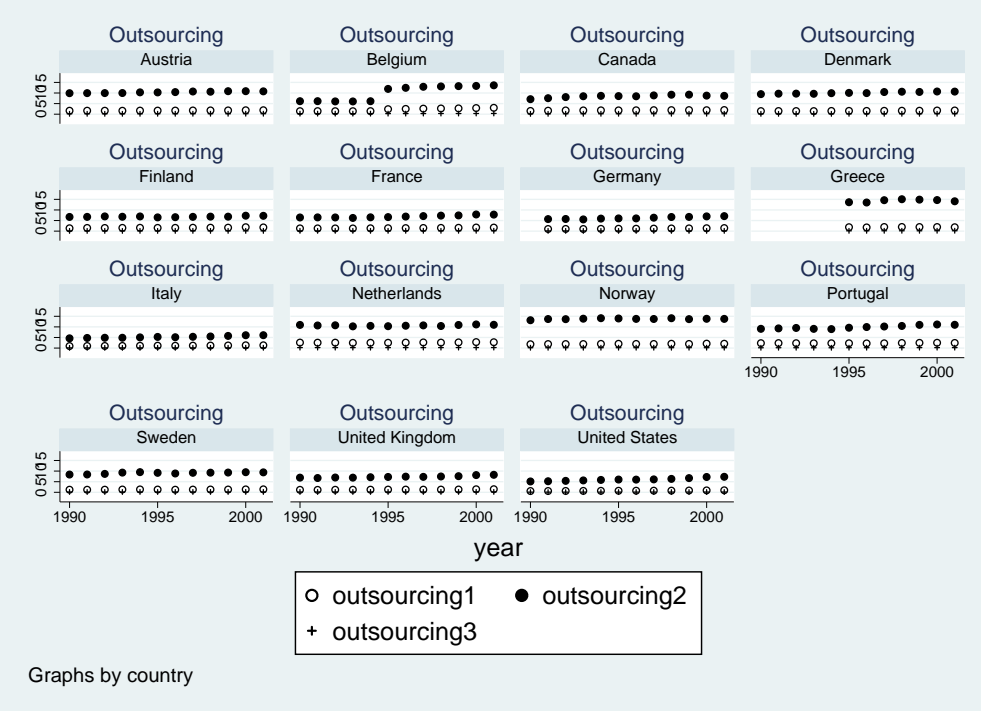




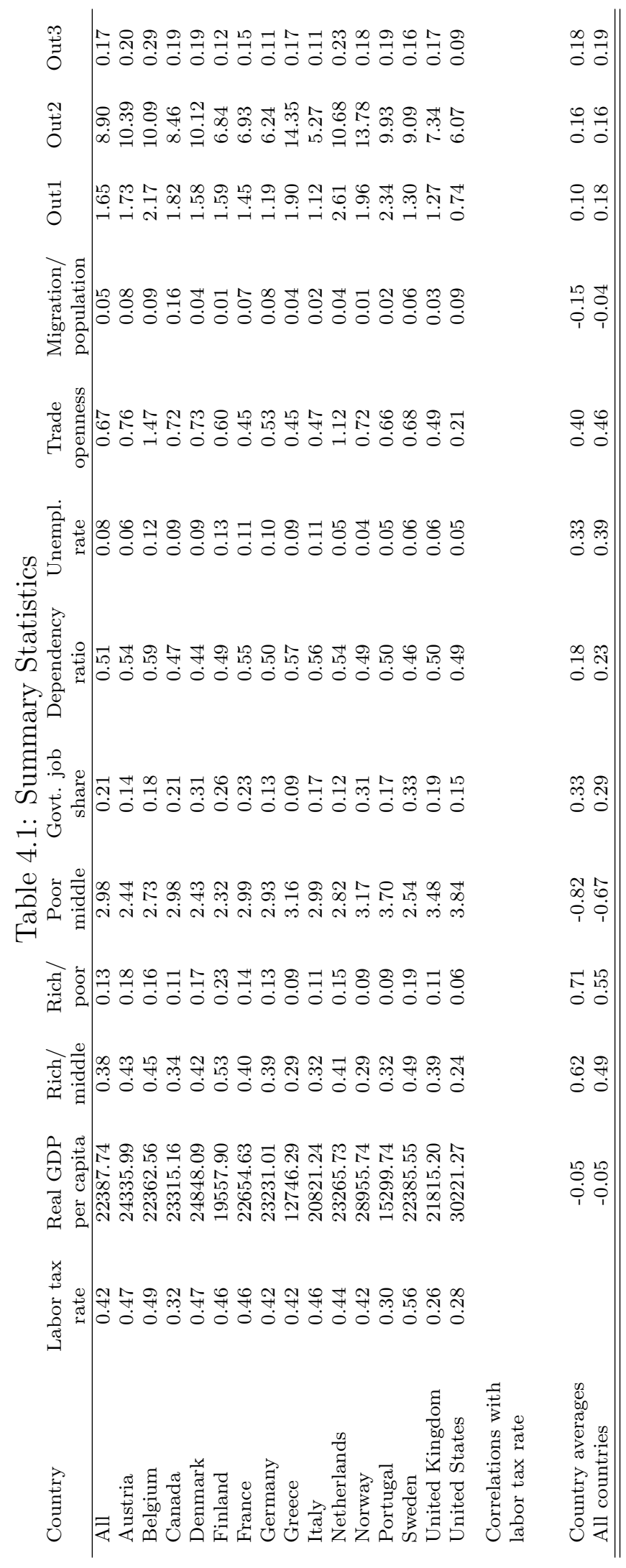




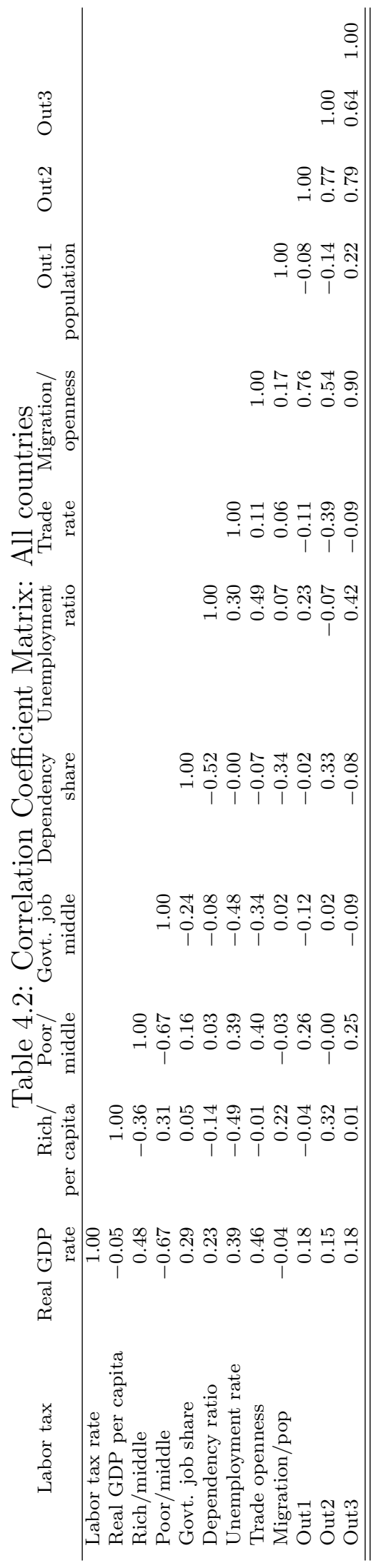




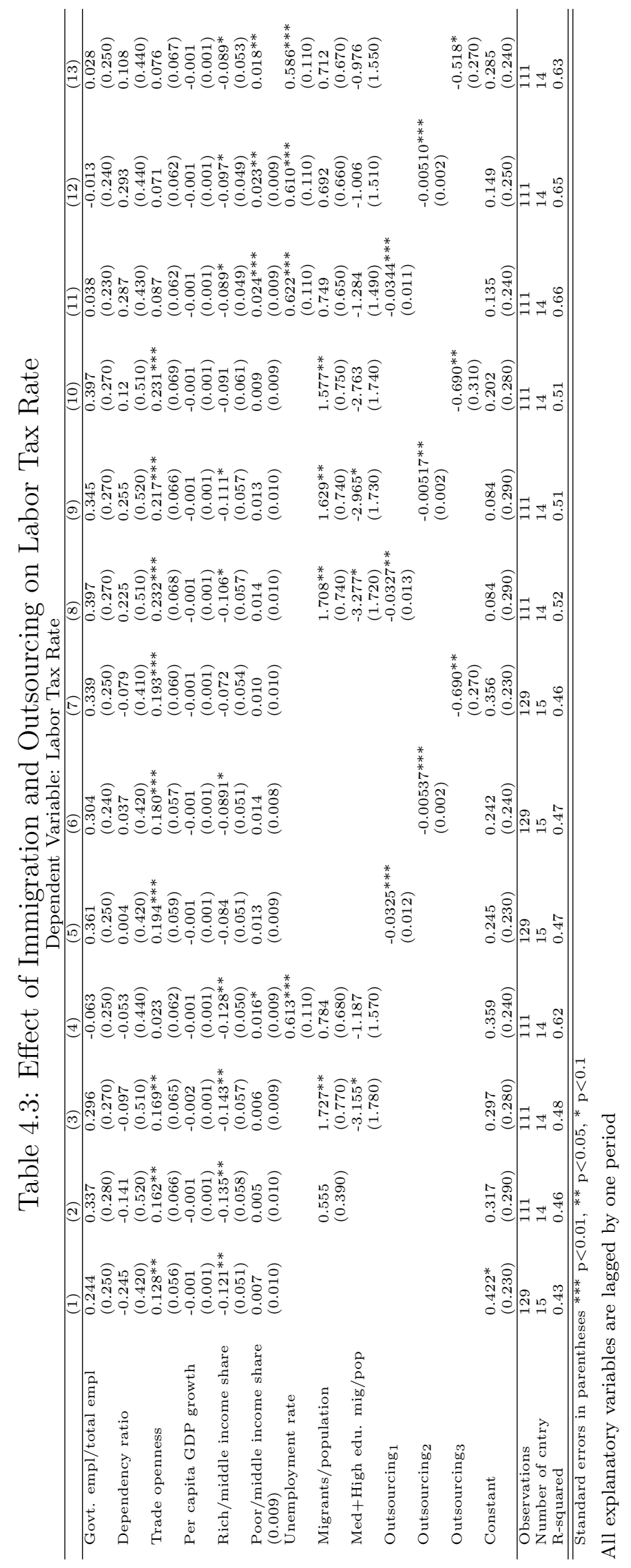




\section{Chapter 5}

\section{Conclusion}

The purpose of this research is to provide new insights in an important aspect of globalization, namely international mobility of capital and labor. The effectiveness of public policies, both in terms of direction and intensity varies according to the flexibility with which factors of production can leave and enter a country.

The essays in this dissertation consecutively provide evidence on the immense growth in capital mobility and analyze the impact of increased labor mobility on domestic tax rates both empirically and theoretically.

The main conclusions of the dissertation are first, there has been phenomenal growth in the international mobility of capital in the last thirty years, and the noticeable part of this growth is observed during the nineties, typically referred to as the globalization period. Two alternative approaches, namely employing the saving-investment correlation coefficient and the balance of trade and investment correlation coefficient equally support the hypothesis of increasing capital mobility. Thus the Feldstein-Horioka puzzle revealing capital immobility in OECD countries disappears and what emerges from this research is the pattern in which the increase in capital mobility has taken place.

The future course of this finding is directed towards identifying the sources that led to the sudden growth in capital mobility during the nineties. The role of government policies 
as well as institutional factors need to be evaluated in this context.

Secondly, labor mobility, which no longer is restricted to the concept of immigration, but extends further to include outsourcing has profound implications for domestic fiscal policies.

The main findings are that an increase in international outsourcing of low skill jobs leads to lower labor taxes and higher profit taxes. The deeper implications of the theoretical model is that we should observe low labor taxes and high profit taxes in the developed countries that have over time been increasingly sending low skill jobs abroad to make use of cheap labor. Contrarily, the low income labor intensive countries providing distant low skill services to the outsourcing firms should exhibit high labor taxes and low profit taxes.

Finally an empirical application of the model presenting an analysis of a set of OECD countries imply that an increase in low skill immigration increases domestic labor tax rate whereas an increase in low skill outsourcing reduces it.

The results imply that the fact that immigration and outsourcing are "mirror images" cannot be generalized; if we look at the two from a public finance perspective they both significantly affect domestic tax burden but in very different and rather opposite ways.

The findings of this study further reinforce some earlier work on the effect of outsourcing on domestic workers. It has been claimed in earlier literature that outsourcing increases productivity (and, hence, real wages) of domestic low-skill workers. From a political economy perspective, it can be argued that this group of workers will then have incentives to join the high-income group and vote for lower domestic labor tax rates. Along this same line of reasoning, and light of our results, low skilled immigration should not have the same impact as foreign outsourcing on labor productivity. 


\section{Bibliography}

Anderton, B., Brenton, P., 1997. Outsourcing and low-skilled workers in the uk, london:National Institute of Economic and Social Research mimeo.

Antrás, P., Garicano, L., Rossi-Hansberg, E., 2006. Offshoring in a knowledge economy. Quarterly journal of economics 121 (1), 31-77.

Ball, L., 2006. Has globalization changed inflation? NBER working paper no. 12687.

Bandyopadhyay, S., Wall, H. J., 2006. Immigration and outsourcing: A general equilibrium analysis. Working paper series, West Virginia University (06-15).

Baxter, M., Crucini, M., 1993. Explaining saving investment correlations. American Economic Review 83, 416-36.

Blanchard, O., Giavazzi, F., 2002. Current account deficits in the euro area. the end of the feldstein horioka puzzle? Brookings Papers on Economic Activity 2002 (2), 187-209.

Borjas, G. J., 1994. Immigration and welfare, 1970-1990. NBER Working Paper Series (4872).

Borjas, G. J., 2006. The impact of immigration on the labor market, prepared for the conference on labor and capital flows in Europe following enlargement, organized by the International Monetary Fund, the joint Vienna Institute and the National Bank of Poland.

Camarota, S. A., 1998. Does immigration harm the poor? The Public Interest (133).

Campa, J., Goldberg, L. S., 1997. The evolving external orientation of manufacturing industries: Evidence from four countries. NBER Working Paper No. 5919.

Coakley, J., Kulasi, F., 1997a. Cointegration of long run saving and investment. Economics Letters 54, 1-6.

Coakley, J., Kulasi, F., 1997b. Cointegration of long run saving and investment. Economics Letters 54, 1-6.

Coakley, J., Kulasi, F., Smith, R., 1994. The saving investment association. Working Paper (10/94), Buehler:Haucap:200.

Coakley, J., Kulasi, F., Smith, R., 1995b. The relationship between cross section, time series and other estimators of the fh regression. Mimeo. 
Coakley, J., Kulasi, F., Smith, R., 1996a. Current account solvency and the feldstein-horioka puzzle. Economic Journal 106, 620-627.

Coakley, J., Kulasi, F., Smith, R., 1996b. Saving, investment and capital mobility in ldes. Working Paper 10/96.

Coakley, J., Kulasi, F., Smith, R., 1998. The feldstein-horioka puzzle and capital mobility: A review. International Journal of Finance and Economics 3, 169-188.

Coleman, D., Rowthorn, R., Dec. 2004. The economic effects of immigration into the united kingdom. Population and Development Review 30 (4), 579-624.

Daveri, F., Tabellini, G., April 2000. Unemployment, growth and taxation in industrial countries. Economic Policy 15 (30), 49-104.

Deninger, K., Squire, L., 1996. A new dataset measuring income inequality. World Bank Economic Review 10, 565-591.

Dolmas, J., Huffman, G. W., November 2004. On the political economy of immigration and income redistribution. International Economic Review 45 (4), 1129-1168.

Dooley, M., Frankel, J., Mathieson, D. J., Sept 1987. International capital mobility: What do saving-investment correlations tell us? IMF Staff Papers 34, 503-30.

Eeckhout, J., Jovanovic, B., 2007. Occupational choice and development, nBER working paper no. 13686.

Egger, H., Egger, P., January 2006. International outsourcing and the productivity of lowskilled labor in the eu. Economic Inquiry 44 (1), 98-108.

Feenstra, R. C., Hanson, G. H., May 1996. Globalization, outsourcing and wage inequality. American Economic Review 86 (2), 240-245.

Feenstra, R. C., Hanson, G. H., 1999. The impact of outsourcing and high-technology capital on wages: Estimates for the united states 1979-1990. Quarterly Journal of Economics 114, 907-40.

Feldstein, M., 1983. Domestic saving and international capital movements in the long run and the short run. European Economic Review 21, 129-51.

Feldstein, M., December 2005. Monetary policy in a changing international environment: The role of capital flows. Working Paper (w11856).

Feldstein, M., May/June 2006. The return of saving. Foreign Affairs.

Feldstein, M., Bacchetta, P., 1991. National saving and international investment. D. Bernheim and J. Shoven(eds.), National Saving and Economic Performance, 201-206.

Feldstein, M., Horioka, C., 1980. Domestic saving and international capital flows. The Economic Journal 90 (358), 314-329. 
Frankel, J., 1991. Quantifying international capital mobility in the 1990s. D. Bernheim and J. Shoven eds., National Saving and Economic Performance, 227-60.

Frankel, J. A., 1986. International capital mobility and crowding out in the us economy: Imperfect integration of financial markets or of goods market. R.W.Hafer (Ed.) How Open is the US Economy, 33-67.

Frankel, J. A., 1992. Measuring international capital mobility - a review. American Economic Review 82, 197-202.

Ghosh, A. R., 1995. International capital mobility among the major industrialized countries: Too little or too much. The Economic Journal 105, 107-128.

Grossman, G. M., Rossi-Hansberg, E., July 2006. The rise of offshoring: It's not wine for cloth anymore, unpublished Working Paper.

Gundlach, E., Sinn, S., 1992. Unit root test of the current account balance: Implication for international capital mobility. Applied Economics 26, 617-625.

Hanson, G. H., Scheve, K. F., Slaughter, M. J., 2005. Public finance and individual preferences over globalization strategies. NBER Working Papers (11028).

Harberger, A., 1980. Vignettes on the world capital market. American Economic Review 70, $331-337$.

Head, K., Ries, J., October 2000. Offshore production and skill upgrading by japanese manufacturing firms. Journal of International Economics 58 (1), 81-106.

Herwartz, H., Xu, F., June 2006. Panel data model comaprison for empirical savinginvestment relations. Economics Working Paper (2006-06).

Hsieh, C.-T., Woo, K. T., 1999. The impact of outsourcing to china on hong kong's labor market, princeton university mimeo.

Jones, R. W., 2005. Immigration vs. outsourcing: Effects on labor markets. International Review of Economics and Finance 14 (2), 105-114.

Kremer, M., Maskin, E., 2003. Globalization and inequality.

Mamingi, N., 1994. Savings-investment correlations and capital mobility in developing countries. The World Bank Policy Research Working Paper (1211).

Mankiw, N. G., Swagel, P., December 2005. The politics and economics of offshore outsourcing. AEI Working Paper (122).

Mark, N. C., Ogaki, M., Sul, D., June 2004. Dynamic seemingly unrelated cointegrating regression. Ohio State University Department of Economics Working Paper (04-02).

Mendoza, E., Razin, A., Tesar, L. L., 1994. Effective tax rates in macroeconomics crosscountry estimates of tax rates on factor incomes and consumption. Journal of Monetary Economics 34, 297-323. 
Miller, S. M., 1988. Are saving and investment cointegrated? Economic Letters 27, 31-34.

Murphy, R. G., 1984. Capital mobility and the relationship between saving and investment rates. Journal of International Money and Finance 3, 327-42.

Nelson, M., Ogaki, M., Sul, D., 2004. Dynamic seemingly unrelated cointegrating regression. Ohio State Department of Economics Working Paper (04-02).

Obstfeld, M., 1986. Capital mobility in the world economy: Theory and measurement. Carnegie-Rochester Conference Series on Public Policy 24, 55-104.

Obstfeld, M., Rogoff, K., 1995. The intertemporal approach to the current account. G.M.Grossman and K. Rogoff(eds.) Handbook Of International Economics 3, 1731-99.

Oltheten, E., Pinteris, G., Sougiannis, T., 2003. Greece in the european union: Policy lessons from two decades of membership.

Penati, A., Dooley, M., 1984. Current account imbalances and capital formation in the industrialized countries. IMF Staff Papers 31, 1-24.

Peri, G., Sparber, C., 2006. Task specialization, comparative advantages and the effects of immigration on wages, working paper.

Pimpão, J. F., 2003. The portuguese economy after the entry to the european union.

Razin, A., Sadka, E., Swagel, P., 2002. Tax burden and migration: a political economy theory and evidence. Journal of Public Economics 85, 167-190.

Rodrik, D., 1997. Has globalization gone too far? Institute for International Economics.

Sachs, J. D., 1981. The current account and macroeconomic adjutsment in the 1970s. Brookings Papers on Economic Activity 1, 201-68.

Sachs, J. D., 1983. Aspects of the current account behavior of oecd economies. Recent Issues in the Theory of Flexible Exchange Rates, ed. by E. Classen and P. Salin.

Saint-Paul, G., April 1994. Unemployment, wage rigidity and returns to education. European Economic Review 38 (3/4).

Sinn, S., 1992. Saving-investment correlations and capital mobility: On the evidence from annual data. The Economic Journal 102 (414), 1162-70.

Slaughter, M. J., 1995. Multinational corporations, outsourcing and american wage divergence. NBER Working Paper No. 5253.

Smith, J. P., Edmonston, B. (Eds.), 1977. The New Americans: Economic, Demographic, and Fiscal Effects of Immigration. Washington, DC: National Academy Press.

Tabellini, D., April 2000. Unemployment and taxes: do taxes affect the rate of unemployment. Economic Policy, 49-104. 
Takashima, R., 2007. The impact of trade and factor flows on domestic taxation. International Journal of Business and Economics 6 (1), 47-62.

Yomogida, M., Zhao, L., 2005. The labor market effects of fragmentation, outsourcing and immigration:two sides of the same story?, unpublished working paper. 


\section{Appendix A}

\section{Description of Data - Capital Mobility}

This paper follows Feldstein and Horioka and restricts the study to OECD countries for the main conclusion. However, the dataset is larger since it includes the whole set of OECD countries, making a total of 29 countries (excluding Luxembourg) 1 The sample period spreads over 34 years starting in 1970, ending at 2003. The regressions for developing countries uses data on saving, investment and GDP for 61 developing countries.

Data on Gross Domestic Investment (as share of GDP), Gross Domestic Savings (as a share of GDP), Current account balance (as a share of GDP) and GDP for both OECD and developing countries is obtained from World Development Indicators 2005. The variables that we use in our regressions are defined as follows: ${ }^{2}$

GDI $=$ Share of gross domestic investment in GDP. Gross domestic investment consists of outlays on additions to the fixed assets of the economy plus net changes in the level of inventories. Fixed assets include land improvements (fences, ditches, drains, and so on); plant, machinery, and equipment purchases; and the construction of roads, railways, and the like, including schools, offices, hospitals, private residential dwellings, and commercial and industrial buildings. Inventories are stocks of goods held by firms to meet temporary or unexpected fluctuations in production or sales, and "work in progress." According to the 1993 SNA, net acquisitions of valuables are also considered capital formation.

GDS = Share of gross domestic savings in GDP. Gross domestic savings are calculated as GDP less final consumption expenditure (total consumption).

$\mathrm{CA}=$ Current account balance is the sum of net exports of goods, services, net income, and net current transfers.

GDP $=$ GDP at purchaser's prices is the sum of gross value added by all resident producers in the economy plus any product taxes and minus any subsidies not included in the value of the products. It is calculated without making deductions for depreciation of fabricated assets or for depletion and degradation of natural resources. Data are

\footnotetext{
${ }^{1}$ The data set considered in the literature usually excludes Luxembourg since it is considered to be an outlier.

${ }^{2}$ Definitions are quoted from the 2005 World Development Indicators data.
} 
in constant 2000 U.S. dollars. Dollar figures for GDP are converted from domestic currencies using 2000 official exchange rates. 


\section{Appendix B}

\section{Detailed description of "Labor tax rate" and "Outsourcing" measures}

\section{B.1. Labor tax rate $=$ Effective tax rate on labor, $\tau_{l}$}

Reproducing from Mendoza et al. (1994):

$$
\tau_{l}=\left(\frac{\tau_{h} W+2000+3000}{W+2200}\right),
$$

where

$\tau_{h}=1100 /(O S P U E+P E I+W)$,

$1100=$ Taxes on income, profits, and capital gains of individuals;

$2000=$ Total social security contributions;

$2200=$ Employer's contribution to social security;

$3000=$ Taxes on payroll and workforce;

$W=$ Wages and salaries;

$O S P U E=$ Operating surplus of private unincorporated enterprises;

$P E I=$ Household's property and entrepreneurial enterprises.

\section{B.2. Outsourcing ${ }_{i}=$ Outsourcing measured in three different ways, $i=1,2,3$}

All three indicators use import of intermediate inputs, calculated following Grossman and Rossi-Hansberg (2006). The assumption crucial to the calculation is that the ratio of imports to domestic output of a particular industry replicates the ratio of imported intermediates to domestic intermediates. Grossman and Rossi-Hansberg (2006) use this same assumption.

Imports of intermediate goods in the whole economy is thus calculated as a weighted sum of total intermediate goods used in each manufacturing industry, the weights being the share of imports in total output (given by sum of domestic production and imports). Also, data on only 2-digit manufacturing industries are used. In mathematical notation:

$$
\eta_{i}^{M}=\frac{q_{i}^{M}}{\left(q_{i}^{D}+q_{i}^{M}\right)} \eta_{i},
$$


where, for industry $i$,

$\eta=$ Total intermediate inputs;

$\eta^{M}=$ Imported intermediate inputs;

$q^{M}=$ Total imports;

$q^{D}=$ Total domestic production;

Once we obtain $\eta_{i}^{M}$, we can construct the three different measures of outsourcing used in the empirical analysis of our paper as follows.

\section{B.3. Outsourcing 1}

This measure is constructed following Egger and Egger (2006). It is defined as the share of intermediate imports in the same 2-digit industries in total production. For every country $c$, year $t$, and industry $i$, Outsourcing ${ }_{1}$ is calculated as follows:

$$
\text { Outsourcing }{ }_{1}=\sum_{i} \frac{D_{i c} \cdot \eta_{i t c}}{Y_{i t c}}
$$

where,

$D_{i c}=$ Diagonal term of 2-digit input output matrix divided by total intermediates used by industry $i ; D_{i c}$ is assumed to be constant; our paper uses 1995 data for $D_{i c}$; and $Y_{i t c}=$ Total production.

\section{B.4. Outsourcing 2}

The second indicator of outsourcing is defined as the share of imported intermediate inputs in total non-energy intermediates. This is also termed the "broad" measure of outsourcing in Feenstra and Hanson (1999). Again, input output tables for non-energy intermediates are available only for 1995 and 2000.

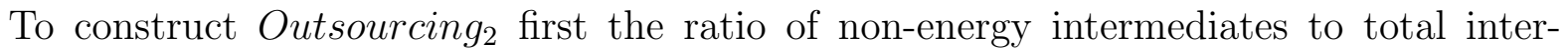
mediates in 1995 is calculated. This is a fixed number which is then multiplied by total intermediate inputs for all years to get the total non-energy intermediates usage by each industry in all countries over the entire period.

Mathematically,

$$
\begin{aligned}
\eta_{i, 1995, c}^{n e} & =\left(\frac{\text { non-energy intermediate }}{\text { total intermediate }}\right)_{1995} \\
\eta_{i, t, c}^{n e} & =\eta_{i, 1995, c}^{n e} \times \text { total intermediates }
\end{aligned}
$$

where,

$\eta^{n e}=$ Total non-energy intermediates.

Hence,

$$
\text { Outsourcing }_{2}=\sum_{i} \frac{\eta_{i t c}^{M}}{\eta_{i t c}^{n e}}
$$




\section{B.5. Outsourcing}

The third indicator of outsourcing shows the share of imported intermediate inputs in total production, a measure constructed following Grossman and Rossi-Hansberg (2006): :

$$
\begin{aligned}
\text { Outsourcing }_{3} & =\frac{\sum_{i} \eta_{i t c}^{M}}{\sum_{i} Y_{i t c}}, \\
& =\frac{\eta_{t c}^{M}}{Y_{t c}} .
\end{aligned}
$$

${ }^{1}$ Grossman and Rossi-Hansberg (2006) also construct another measure of outsourcing, namely the share of imported intermediate inputs in total intermediates. Our analysis does not include this measure since the Feenstra-Hanson measure already takes into account non-energy intermediates. We stick to this measure because energy inputs cannot be outsourced anyway. 


\section{Appendix $\mathrm{C}$}

\section{Data Sources}

The study uses data from multiple sources. Effective labor tax rate is constructed with data from National Accounts Volume II and Revenue Statistics published by the OECD. Part of the dataset also draws from Takashima (2007).

The main explanatory variables are share of immigrants in total population and international outsourcing. International Migration Statistics (OECD), provide data on migration and educational classification of migrants for all OECD countries except Norway. The data for Norway is taken from Norway Stat.

Industrial data on total output, total imports and imported and domestic intermediate goods required to measure international outsourcing are taken from the STAN Industrial database and input-output tables published by OECD.

Income inequality measures are constructed using data on income distribution by deciles from the World Inequality Database. The regressions use only high quality data. 11 Other control variables such as unemployment rate, per capita GDP growth rate, employment, and population are taken from International Financial Statistics (IFS). Share of government employment in total employment is also calculated with data from National Accounts Volume II published by the OECD. The Penn World Tables provide data on trade openness.

\footnotetext{
${ }^{1}$ The World Income Inequality Database provides a classification of data on the basis of their quality rating. High quality data refers to the dataset with quality rating " 1 ", which means that this dataset is conceptually sound and has met all the desirable features of a survey, such as coverage issues, data collection methodology and questionnaires.
} 


\section{Sudeshna Pal}

Department of Economics Phone: (304) 685-4997

West Virginia University, P.O. Box 6025 E-Mail: SuPal@mail.wvu.edu

Morgantown, WV 26506-6025

\section{Education}

Ph.D., Economics, West Virginia University, May 2008

M.A., Economics, West Virginia University, August 2005

M.A., Economics, Jawaharlal Nehru University, India, August 2002

B.Sc.(Hons.), University of Calcutta, India, August 2000

\section{Professional Experience}

08/2003-04/2004 Teaching Assistant, Department of Economics (WVU)

05/2004-07/2008 Instructor, Department of Economics (WVU)

Principles of Microeconomics (ECON 201)

Principles of Macroeconomics (ECON 202)

Intermediate Microeconomics (ECON 301)

Intermediate Macroeconomics (ECON 302)

International Economics (ECON 451)

\section{Working Papers for Peer-Review Journals}

"Immigration, Outsourcing and Tax Policy in OECD Countries" with Santiago M. Pinto

"Reassessing International Capital Mobility: The Feldstein-Horioka Puzzle Disappears"

"The Traps in the Outsourcing Game" with Hyungna Oh

\section{Honors and Awards}

Jon Vilasuso Advanced Doctoral Student Award, Department of Economics, West Virginia University, 2007

Kaiser Best Doctoral Student Award, Department of Economics, West Virginia University, 2006 